\title{
Maternal Obesity and Occurrence of Fetal Macrosomia: A Systematic Review and Meta-Analysis
}

\author{
Laura Gaudet, ${ }^{1,2,3}$ Zachary M. Ferraro, ${ }^{2,4}$ Shi Wu Wen, ${ }^{3}$ and Mark Walker ${ }^{1,2,3}$ \\ ${ }^{1}$ University of Ottawa, Faculty of Medicine, 451 Smyth Road, Ottawa, ON, Canada K1H 8M5 \\ ${ }^{2}$ Division of Maternal-Fetal Medicine, Department of Obstetrics, Gynecology \& Newborn Care, The Ottawa Hospital, \\ 501 Smyth Road, Ottawa, ON, Canada K1H 8L6 \\ ${ }^{3}$ Ottawa Hospital Research Institute, Ottawa, ON, Canada K1H 8L6 \\ ${ }^{4}$ Healthy Active Living and Obesity (HALO) Research Group, Children's Hospital of Eastern Ontario, 401 Smyth Road, \\ Ottawa, ON, Canada K1H $8 L 1$ \\ Correspondence should be addressed to Laura Gaudet; lagaudet@ottawahospital.on.ca
}

Received 25 August 2014; Accepted 9 November 2014; Published 7 December 2014

Academic Editor: Francesco Saverio Papadia

Copyright (c) 2014 Laura Gaudet et al. This is an open access article distributed under the Creative Commons Attribution License, which permits unrestricted use, distribution, and reproduction in any medium, provided the original work is properly cited.

\begin{abstract}
Objective. To determine a precise estimate for the contribution of maternal obesity to macrosomia. Data Sources. The search strategy included database searches in 2011 of PubMed, Medline (In-Process \& Other Non-Indexed Citations and Ovid Medline, 1950-2011), and EMBASE Classic + EMBASE. Appropriate search terms were used for each database. Reference lists of retrieved articles and review articles were cross-referenced. Methods of Study Selection. All studies that examined the relationship between maternal obesity (BMI $\geq 30 \mathrm{~kg} / \mathrm{m}^{2}$ ) (pregravid or at 1st prenatal visit) and fetal macrosomia (birth weight $\geq 4000 \mathrm{~g}, \geq 4500 \mathrm{~g}$, or $\geq 90$ th percentile) were considered for inclusion. Tabulation, Integration, and Results. Data regarding the outcomes of interest and study quality were independently extracted by two reviewers. Results from the meta-analysis showed that maternal obesity is associated with fetal overgrowth, defined as birth weight $\geq 4000 \mathrm{~g}$ (OR 2.17, 95\% CI 1.92, 2.45), birth weight $\geq 4500 \mathrm{~g}$ (OR 2.77,95\% CI 2.22, 3.45 ), and birth weight $\geq 90 \%$ ile for gestational age (OR 2.42, 95\% CI 2.16, 2.72). Conclusion. Maternal obesity appears to play a significant role in the development of fetal overgrowth. There is a critical need for effective personal and public health initiatives designed to decrease prepregnancy weight and optimize gestational weight gain.
\end{abstract}

\section{Introduction}

The term macrosomia describes a newborn with an excessively high birth weight indicative of fetal overgrowth. Most studies define macrosomia as a birth weight greater than or equal to $4000 \mathrm{~g}$; however others use $4500 \mathrm{~g}$ as the cutpoint $[1,2]$. There has been further interest in the group of infants whose birth weight exceeds $5000 \mathrm{~g}$ [3]. Based on the variation in cut-points, we propose that macrosomia can be subdivided into Class I (birth weight 4000-4499 g), Class II (4500-4999 g), and Class III ( $\geq 5000 \mathrm{~g})$. Alternatively, fetal overgrowth can be defined as a birth weight greater than the 90th percentile, corrected for gestational age [4].

Excessive growth in the fetus is a major contributor to adverse obstetrical outcomes. Khashu et al. examined the perinatal outcomes of 1842 macrosomic newborns in
British Columbia, and Canada and identified significantly increased maternal risks of emergency Caesarean section, obstetrical trauma, postpartum hemorrhage, and maternal diabetes (all outcomes, $P<0.001$ ) [5]. Further, the infants were at higher risk of having birth trauma, of needing resuscitation, and of having an Apgar score less than seven at five minutes of life $(P<0.001)$ [5]. There is also evidence that macrosomia is associated with shoulder dystocia, brachial plexus injury, skeletal injuries, meconium aspiration, perinatal asphyxia, hypoglycemia, and fetal death [6]. Based on existing literature, there is little doubt that fetal macrosomia is associated with adverse pregnancy outcomes for both mother and infant. In addition, there is a recognized association between fetal macrosomia and long-term consequences for the newborn, including obesity, diabetes, and heart disease [7-20]. 
Although there is a plethora of information available in the literature regarding the contribution of maternal obesity, both preexisting and due to excessive gestational weight gain, to fetal macrosomia, the exact effect size of this relationship remains imprecise $[4,21-40]$. At the time of our analysis, only one previous meta-analysis could be identified, in which the relationship between obesity and fetal overgrowth was examined as a secondary outcome [41]. Therefore, the objective of this project was to systematically review the literature regarding maternal obesity and fetal macrosomia and to complete a meta-analysis to provide the best possible estimate for the increase in macrosomia that can be attributed to maternal obesity.

\section{Sources}

The following databases were searched by a librarian experienced in systematic reviews: PubMed, Medline (In-Process \& Other Non-Indexed Citations and Ovid Medline, 1950-2011), and EMBASE Classic + EMBASE. Databases were searched using a comprehensive and sensitive search strategy aimed at identifying as many studies as possible. The search strategy was formulated with the assistance of the librarians at the University of Ottawa. Results were filtered to include studies involving human subjects. The terms used in PubMed were as follows:

(1) body mass index[mh] AND obesity[mh] AND (pregnancy complications[majr] OR pregnancy outcome[majr]),

(2) ((inprocess[sb]) OR (publisher [sb])) AND (pregnan *[Title] AND obes*[Title]).

The terms used in Medline were as follows:

(1) Exp Obesity/or obesity.mp,

(2) Exp Body Mass Index/or BMI.mp,

(3) 1 and 2,

(4) Exp Pregnancy Complications or pregnancy complica *.mp,

(5) Exp Pregnancy Outcome/or pregnancy outcome *.mp,

(6) 3 or 4 ,

(7) 3 and 6 .

The terms used in EMBASE Classic + EMBASE were as follows:

(1) exp MORBID OBESITY/or exp ABDOMINAL OBESITY/or exp OBESITY/or obesity.mp,

(2) exp body mass/or body mass index.mp,

(3) 1 and 2,

(4) exp pregnancy complication/or pregnancy complic *.mp,

(5) exp pregnancy outcome/or pregnancy outcome*.mp,

(6) 3 or 4 ,

(7) 3 and 6 .
The references for the resulting studies were then reviewed to identify any additional studies that were not identified in the preliminary search. The full texts of articles that were felt to be potentially relevant were obtained. Finally, review articles on obesity and maternal outcomes published between 2000 and 2011 were reviewed and their reference lists searched for additional potential studies. We did not attempt to locate unpublished studies. Electronic messages were sent to some authors to obtain clarification where necessary.

\section{Study Selection}

Observational studies, including prospective and retrospective cohort studies as well as case-control studies were sought for inclusion. To be eligible for inclusion, studies had to identify cases using the Institute of Medicine (IOM) definition of obesity (BMI $\geq 30.0 \mathrm{~kg} / \mathrm{m}^{2}$ ). Maternal obesity defined as prepregnancy, first trimester, or first antenatal visit $\mathrm{BMI} \geq 30 \mathrm{~kg} / \mathrm{m}^{2}$ comprised the exposure variable. There had to be sufficient data present to allow for quantification of the number of obese patients included in the study. Studies also had to identify a control group of women with a BMI in the underweight range (BMI $<18.5 \mathrm{~kg} / \mathrm{m}^{2}$ ), normal weight range (BMI $18.5-24.9 \mathrm{~kg} / \mathrm{m}^{2}$ ), or combined underweight + normal weight range $\left(\mathrm{BMI}<25.0 \mathrm{~kg} / \mathrm{m}^{2}\right)$ that must have been obtained prepregnancy, in the first trimester, or at the first antenatal visit. Studies were included if maternal weight was obtained by self-report or direct measurement and infant birth weight was reported. For the outcome measures, studies had to include data that allowed for quantitative measurement of risk of overgrowth, defined as large for gestational age ( $\geq 90 \%$ ile) or fetal macrosomia ( $\geq 4000 \mathrm{~g}$ and/or $\geq 4500 \mathrm{~g}$ ).

All studies with an English abstract were considered for inclusion. Studies that did not have full text in English were translated for review. All potential studies were assessed for eligibility by the first reviewer (LG) according to the prespecified criteria outlined in the previous sections. Studies and abstracts were screened and duplicates were removed. Data were extracted from each publication by the first reviewer. All identified studies were then reviewed by a second reviewer (ZF) and data extraction completed. Discrepancies regarding inclusion and extraction were then resolved by consensus.

The quality of included studies was assessed using criteria from the Newcastle-Ottawa Quality Assessment Scale [72]. The representativeness of the exposed and control groups, the means by which the exposure was ascertained, and followup rates were assessed. The overall quality of the included studies was then graded as low, moderate, or high according to prespecified criteria. All data were extracted independently by both reviewers and quality grades assigned; discrepancies were resolved by consensus.

A structured data form was developed prior to beginning data abstraction. Data from the different studies were then combined by meta-analysis. Frequencies were then used to generate unadjusted odds ratios and confidence intervals and Forest plots were generated. Meta-analysis was completed using the Comprehensive Meta-Analysis Version 2.0. A random effect model was used to estimate the overall effect 
TABLE 1: Quality assessment criteria.

\begin{tabular}{llll}
\hline $\begin{array}{l}\text { Quality assessment (QA) } \\
\text { variable }\end{array}$ & Low & Moderate & Quality assessment criteria \\
\hline $\begin{array}{l}\text { Representativeness of } \\
\text { exposed cohort }\end{array}$ & $\begin{array}{l}\text { Selected group of users (e.g., } \\
\text { nurses, volunteers) }\end{array}$ & $\begin{array}{l}\text { Somewhat representative of the } \\
\text { average obese pregnant woman in } \\
\text { the community }\end{array}$ & $\begin{array}{l}\text { Truly representative of the average } \\
\text { obese pregnant woman in the } \\
\text { community }\end{array}$ \\
\hline $\begin{array}{l}\text { Source of nonexposed } \\
\text { cohort }\end{array}$ & $\begin{array}{l}\text { Drawn from a different source } \\
\text { than exposed cohort }\end{array}$ & N/A & $\begin{array}{l}\text { Drawn from the same source as the } \\
\text { exposed cohort }\end{array}$ \\
\hline $\begin{array}{l}\text { Ascertainment of } \\
\text { exposure (obesity) }\end{array}$ & Self-report height and weight & Self-report height or weight & Measured height and weight \\
\hline $\begin{array}{l}\text { Comparability of cohorts } \\
\text { Comparable for less than 3 of } \\
\text { the variables assessed }\end{array}$ & $\begin{array}{l}\text { Comparable for 3 or 4 of the } \\
\text { variables assessed }\end{array}$ & $\begin{array}{l}\text { Comparable for at least 5 of the } \\
\text { variables assessed }\end{array}$ \\
\hline $\begin{array}{l}\text { Loss to follow-up rate }>5 \% \text { or } \\
\text { no description of those lost }\end{array}$ & $\begin{array}{l}\text { Subjects lost to follow-up unlikely to } \\
\text { introduce bias (<5\% loss to follow-up } \\
\text { and description of those lost) }\end{array}$ & All subjects accounted for \\
$\begin{array}{l}\text { Majority of QA variables rated } \\
\text { as high, including } \\
\text { ascertainment of exposure }\end{array}$ & $\begin{array}{l}\text { Some QA variables rated as high, } \\
\text { obesity self-reported }\end{array}$ & $\begin{array}{l}\text { Few QA variables rated as high, } \\
\text { obesity self-reported }\end{array}$ \\
\hline
\end{tabular}

[73]. To assess statistical heterogeneity and its magnitude, we used Cochran's $Q(\alpha=0.10)$ and the $I^{2}$ statistic, respectively. A sensitivity analysis was then undertaken, including assessment of the effect of study quality.

\section{Results}

Thirty studies met the inclusion criteria (Figure 1). The quality of studies was assessed for those included and excluded. Criteria for quality assessment were determined a priori (Table 1). Four studies were judged to be of high quality, fifteen were of moderate quality and eleven were of low quality. Quality assessment of the included studies $[23,24,42-46,48-$ $59,61-69,71,74]$ can be found in Table 2 and characteristics of excluded $[4,6,21,25,27-29,31,34-39,47,60,70,75-$ 307] studies can be found in Table 3. Of the included studies, nine were conducted in the United States, four in the United Kingdom, four in Denmark, two in Canada, two in Germany, and one in each of Hong Kong, Australia, Norway, Italy, India, France, Finland, Saudi Arabia, and the West Indies. Thus, the information in this review applies primarily to upper/middle income countries according to the World Bank classification [308]. The year of publication ranged from 1992 to 2010. Of included studies, eight had prospective cohort design, twenty-one had retrospective cohort design, and 1 was a retrospective case-control study. Eleven of the studies were conducted using population-based databases; these studies contributed 1,443,449 women to the meta-analysis.

When studies were reviewed, the outcome measures of interest were identified. Six studies reported on more than one outcome measure; information for all relevant outcome measures was abstracted. Thus, thirteen studies reported on LGA, sixteen reported on macrosomia $\geq 4000 \mathrm{~g}$, and eight reported on macrosomia $\geq 4500 \mathrm{~g}$. In the thirteen studies that examined the relationship between maternal obesity and infant birth weight $\geq 90 \%$ ile, there were a total of 162,183 obese parturients. The control group consisted of

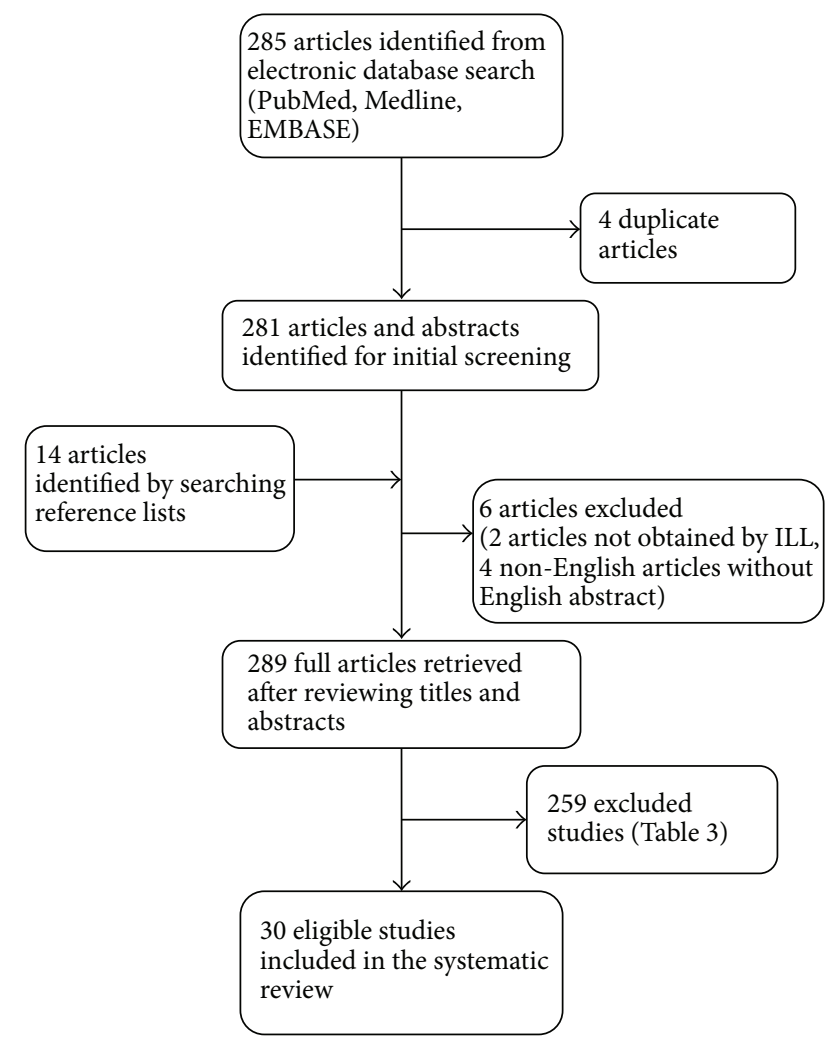

Figure 1: Study flow diagram.

$1,072,397$ underweight or normal weight women. A total of 214,385 infants were large for gestational age (17.4\%). Of these, 36,293 were born to obese mothers; thus, $22.4 \%$ of obese mothers gave birth to an LGA baby. By comparison, $16.6 \%$ of underweight or normal weight mothers gave birth to an LGA baby $(n=178,092)$. Meta-analysis revealed an overall unadjusted odds ratio of $2.42(2.16,2.72)$ (Table 4, Figure 2$)$.

In the sixteen studies that examined the relationship between maternal obesity and macrosomia $\geq 4000$ g, 


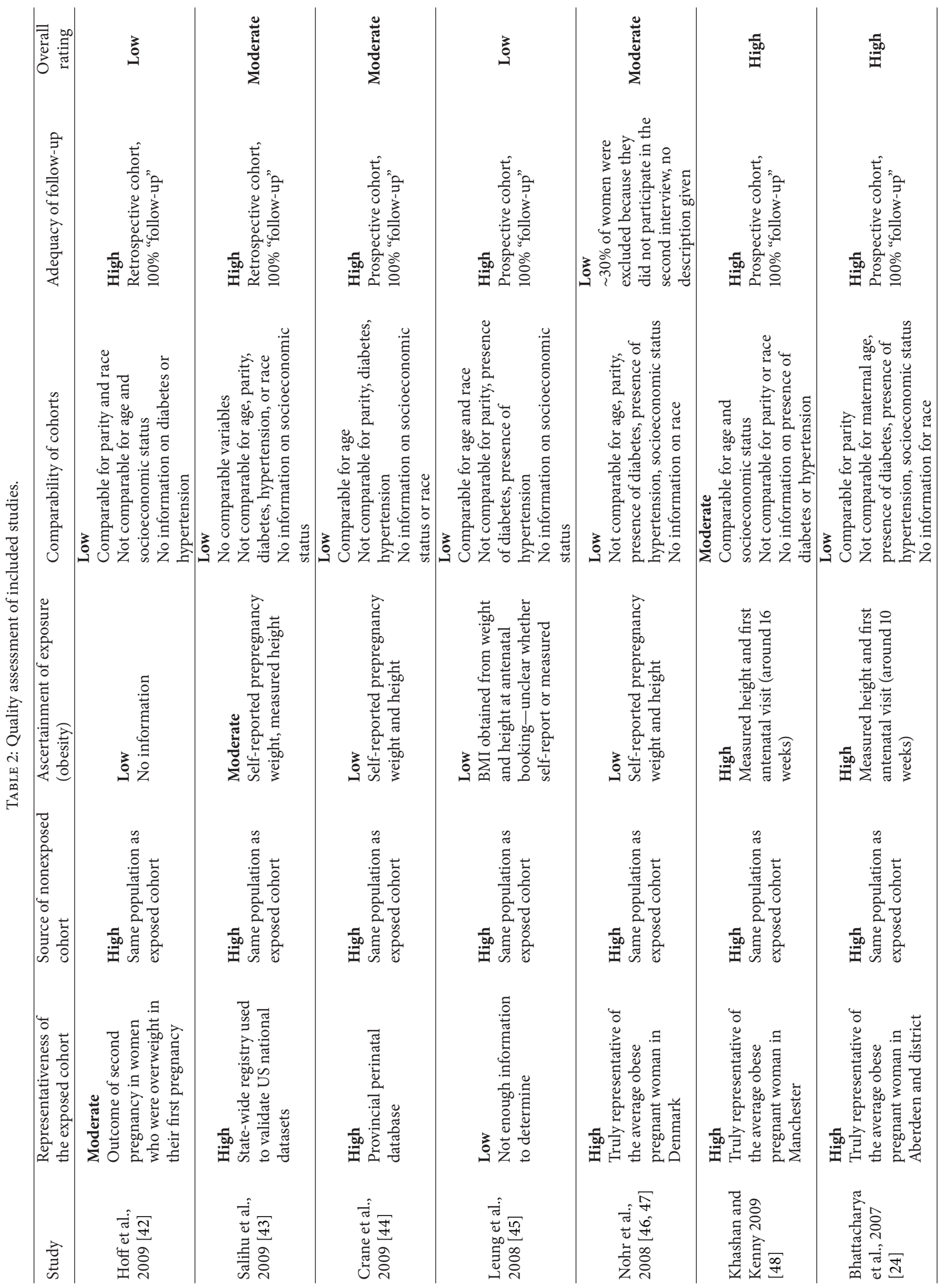




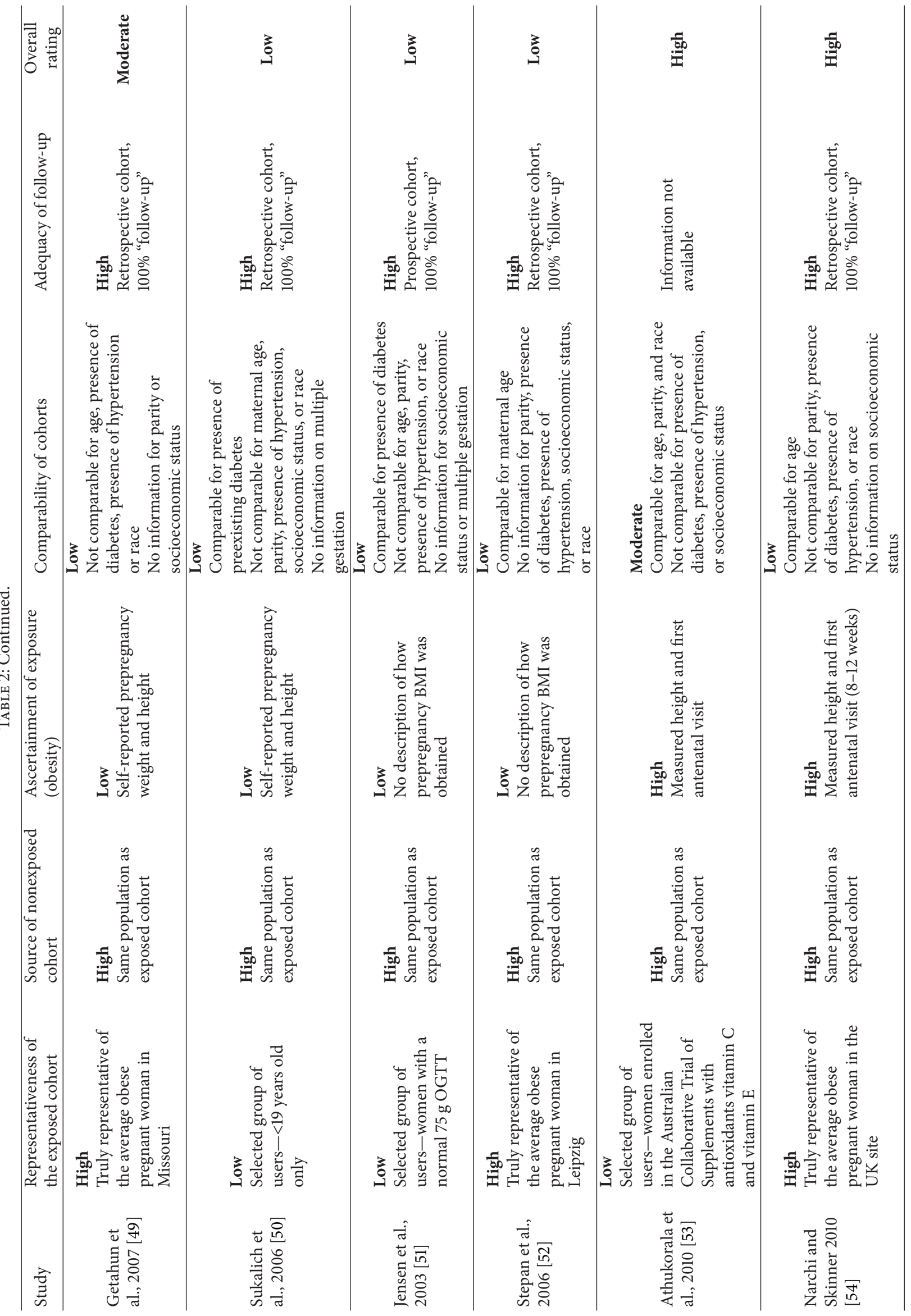




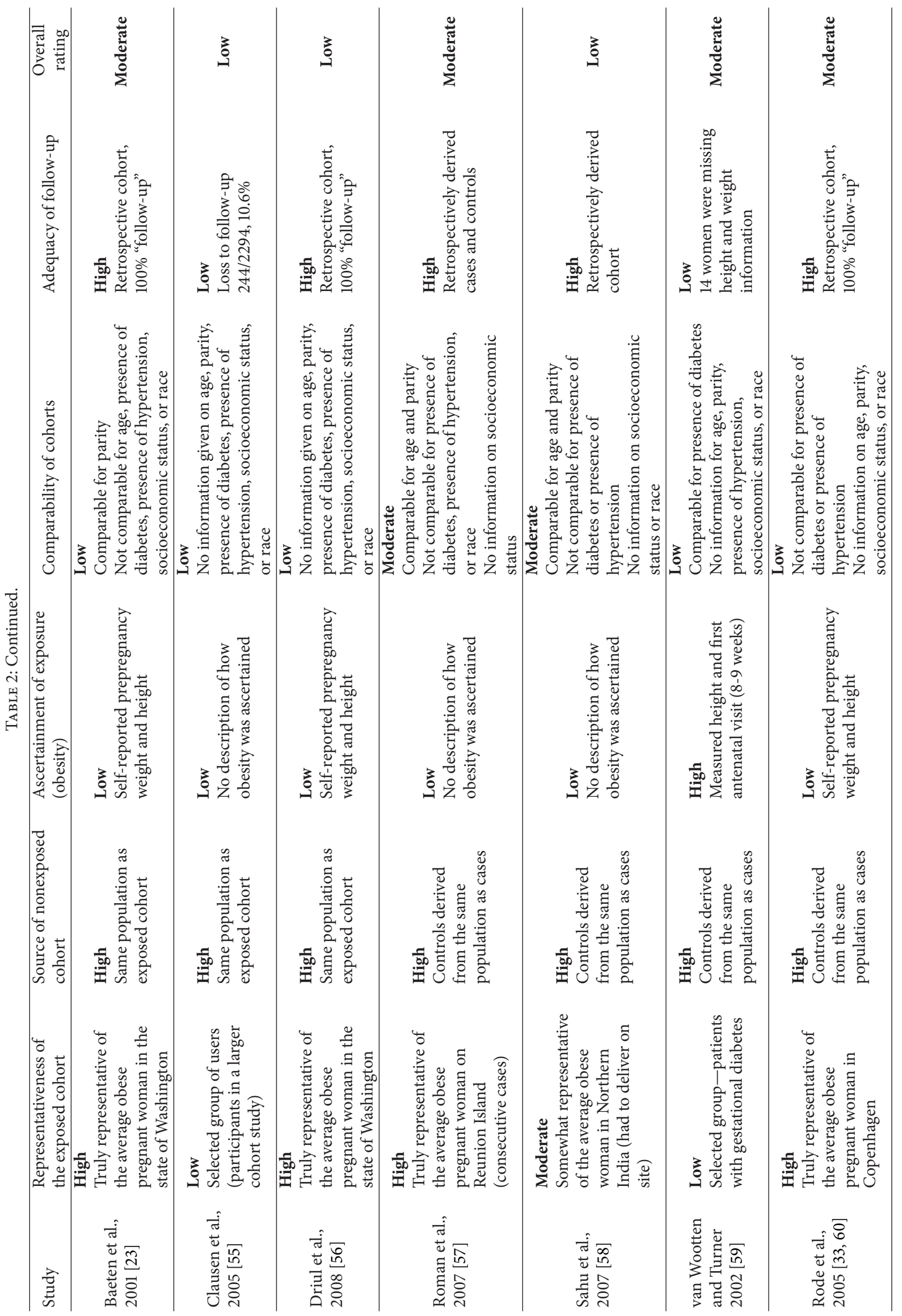




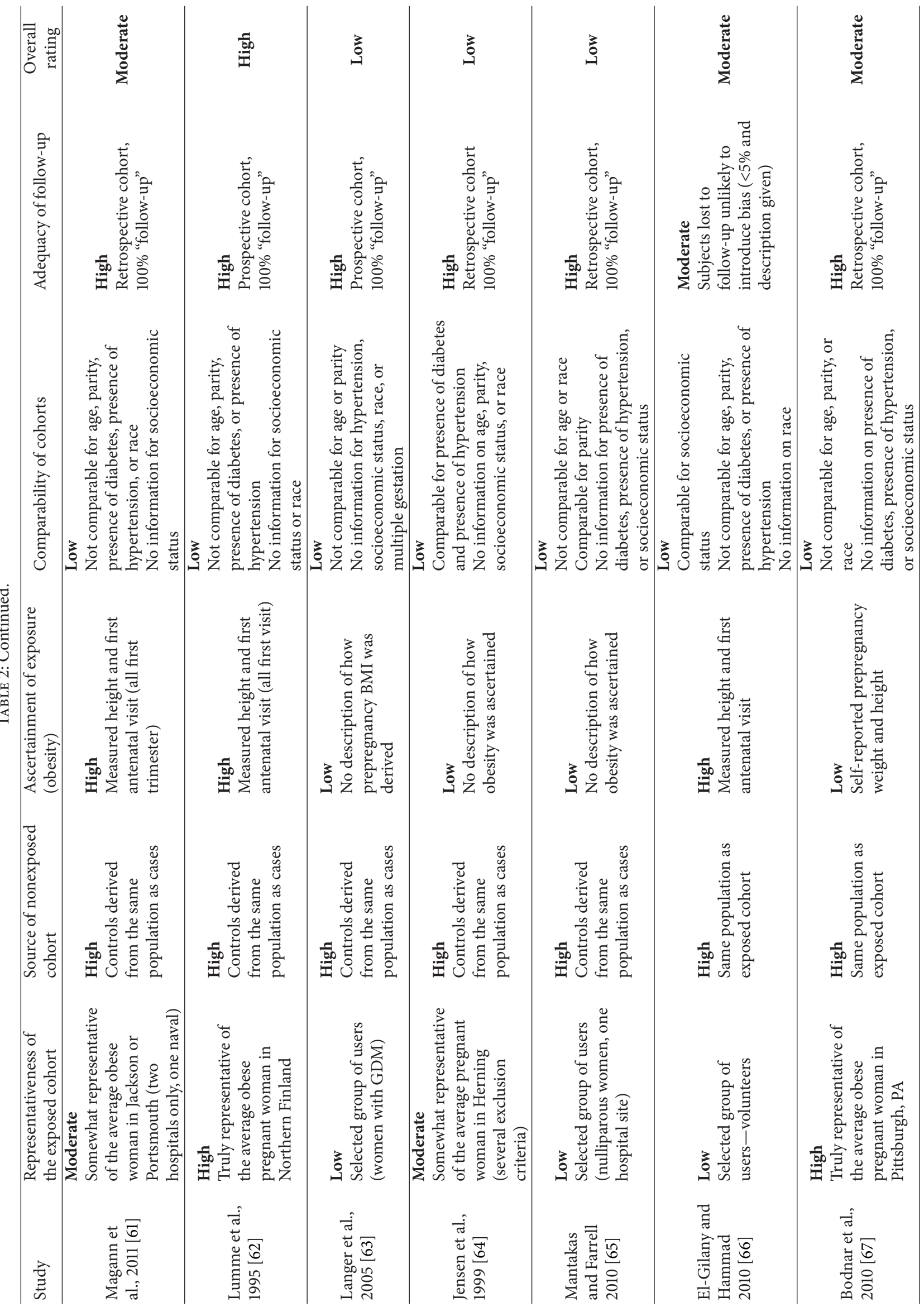




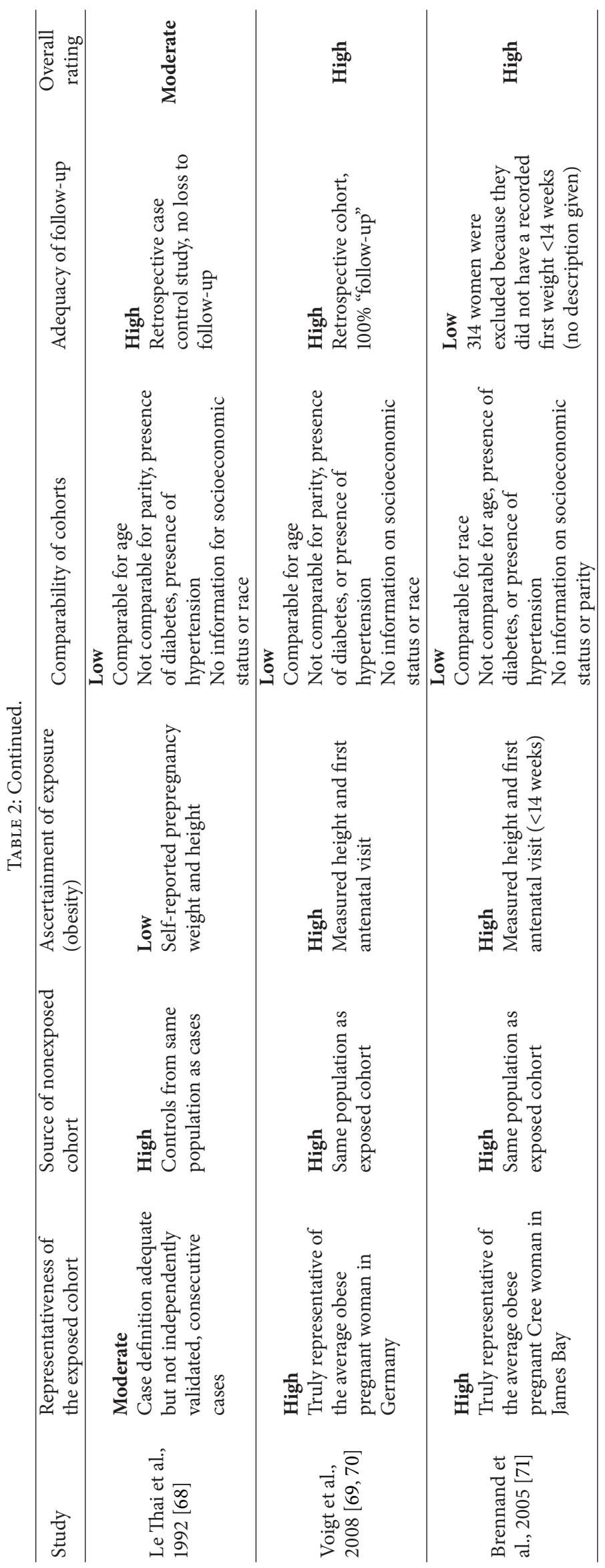


TABLE 3: Characteristics of excluded studies.

\begin{tabular}{lc}
\hline Reason for exclusion & Number of studies excluded \\
\hline Unrelated topic & 62 \\
Obesity not defined as BMI $\geq 30 \mathrm{~kg} / \mathrm{m}^{2}$ & 83 \\
Obesity measure not prepregnancy, first trimester, or first antenatal visit & 5 \\
Comparison group not one of BMI $18.5-24.9 \mathrm{~kg} / \mathrm{m}^{2}$ or BMI $<25.0 \mathrm{~kg} / \mathrm{m}^{2}$ & 32 \\
Data not present to allow quantitative analysis of obesity & 15 \\
Data not present to allow quantitative analysis of macrosomia & 29 \\
Meta-analysis & 1 \\
Review article & 24 \\
Comment & 3 \\
Case report & 1 \\
Duplicate articles & 4 \\
Total number excluded & \\
\end{tabular}

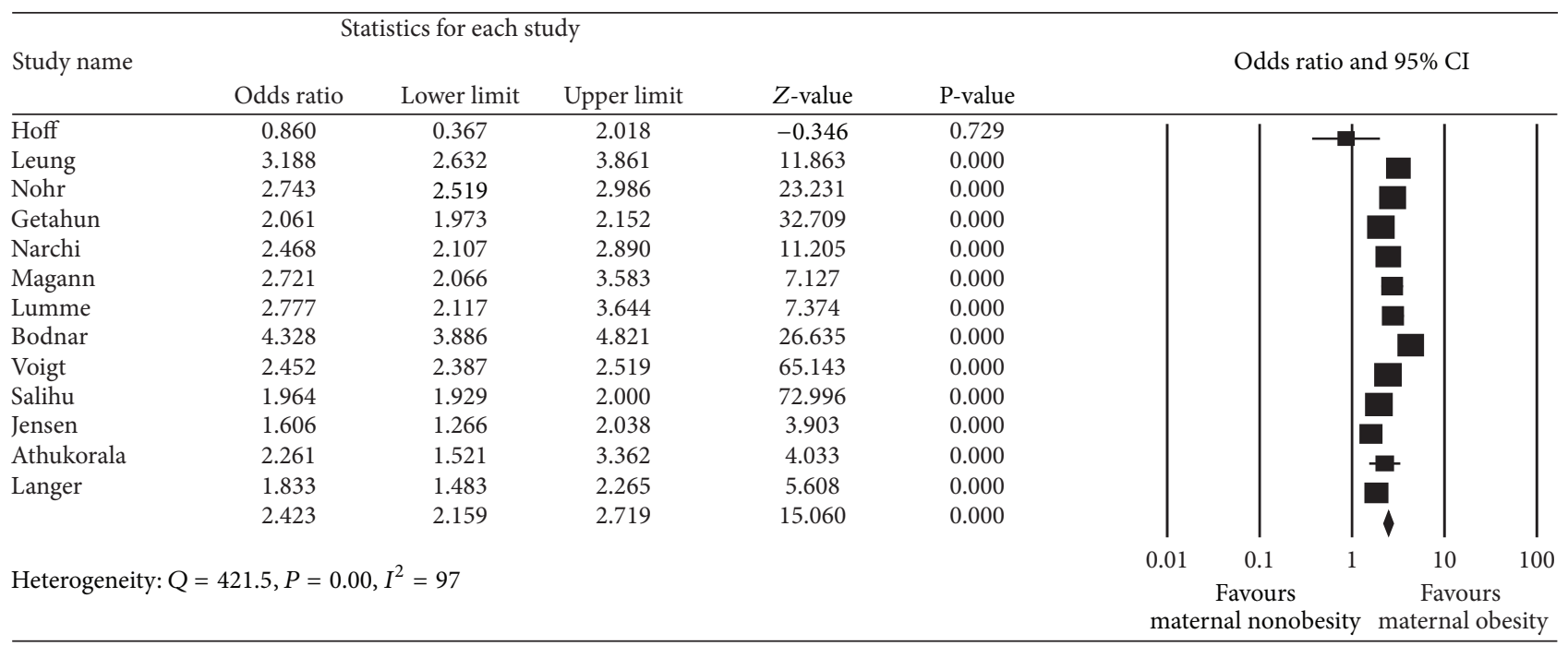

FIgURE 2: Forest plot for large for gestational age ( $>90 \%$ ile).

there were a total of 20,693 obese parturients. The control group consisted of 110,696 underweight or normal weight women. A total of 13,612 infants had a birth weight $\geq 4000 \mathrm{~g}$ $(10.4 \%)$. Of these, 3,275 were born to obese mothers; thus, $15.8 \%$ of obese mothers gave birth to a macrosomic baby weighing $\geq 4000 \mathrm{~g}$. By comparison, $9.3 \%$ of underweight or normal weight mothers gave birth to a macrosomic baby weighing $\geq 4000 \mathrm{~g}(n=10,337)$. Meta-analysis revealed an overall unadjusted odds ratio of $2.17(1.92,2.45)$ (Table 3 , Figure 3).

In the eight studies that examined the relationship between maternal obesity and macrosomia $\geq 4500 \mathrm{~g}$, there were a total of 18,909 obese parturients. The control group consisted of 62,712 underweight or normal weight women. A total of 1,739 infants had a birth weight $\geq 4500 \mathrm{~g}(2.1 \%)$. Of these, 746 were born to obese mothers; thus, $3.9 \%$ of obese mothers gave birth to an LGA baby. By comparison, $1.6 \%$ of underweight or normal weight mothers gave birth to an LGA baby $(n=993)$. Meta-analysis revealed an overall unadjusted odds ratio of $2.77(2.22,3.45)$ (Table 3 , Figure 4$)$.

There was some important clinical heterogeneity between the included studies. For example, some studies included only normal weight patients in the control (17/30) while others included normal weight and underweight women (13/30). Also, most studies determined BMI using selfreported prepregnancy weight or did not provide information on how BMI was derived (20/30), while those studies that used measured weights had differing criteria for when that weight was measured (varied from $<8$ weeks to $<16$ weeks). Furthermore, some studies excluded women with hypertension or diabetes, while others included them.

There was also a marked amount of statistical heterogeneity, as assessed by the $I^{2}$ statistic. For obese women, the $I^{2}$ value for LGA was $97 \%$, for macrosomia of $\geq 4000 \mathrm{~g}$ the $I^{2}$ value was $69 \%$, and for macrosomia of $\geq 4500 \mathrm{~g}$ the $I^{2}$ value was $48 \%$. These indicate diverse results and a large 
TABLE 4: Association between maternal obesity and fetal overgrowth (odds ratios for individual studies and meta-analysis results).

\begin{tabular}{|c|c|c|c|}
\hline $\begin{array}{l}\text { Outcome of } \\
\text { subgroup title }\end{array}$ & Study & Calculated unadjusted odds ratio & Reported adjusted odds ratio \\
\hline \multirow{14}{*}{$\begin{array}{l}\text { Large for } \\
\text { gestational age } \\
(\geq 90 \text { th } \\
\text { percentile) }\end{array}$} & Hoff et al., 2009 [42] & $0.86(0.37,2.02)$ & N/A \\
\hline & Leung et al., 2008 [45] & $3.19(2.63,3.87)$ & $3.39(2.78,4.13)$ \\
\hline & Nohr et al., $2008[46,47]$ & $1.97(1.81,2.14)$ & N/A \\
\hline & Getahun et al., 2007 [49] & $2.06(1.97,2.15)$ & $\mathrm{N} / \mathrm{A}$ \\
\hline & Narchi and Skinner, 2010 [54] & $2.47(2.11,2.89)$ & $1.4(1.3,1.5)$ \\
\hline & Magann et al., 2011 [61] & $2.72(2.07,3.58)$ & $3.10(2.32,4.15)$ \\
\hline & Lumme et al., 1995 [62] & $2.78(2.12,3.64)$ & $2.3(1.7,3.0)$ \\
\hline & Bodnar et al., 2010 [67] & $4.33(3.89,4.82)$ & N/A \\
\hline & Voigt et al., $2008[69,70]$ & $2.54(2.39,2.52)$ & N/A \\
\hline & Salihu et al., 2009 [43] & $1.96(1.93,2.00)$ & $\mathrm{N} / \mathrm{A}$ \\
\hline & Jensen et al., 2003 [51] & $1.61(1.27,2.04)$ & N/A \\
\hline & Athukorala et al., 2010 [53] & $2.26(1.52,3.36)$ & $2.08(1.47,2.93)$ \\
\hline & Langer et al., 2005 [63] & $1.83(1.48,2.26)$ & N/A \\
\hline & Total & $2.13(2.10,2.16)$ & N/A \\
\hline \multirow{17}{*}{$\begin{array}{l}\text { Macrosomia } \\
\text { (birth weight } \\
\geq 4000 \mathrm{~g} \text { ) }\end{array}$} & Bhattacharya et al., 2007 [24] & $2.17(1.89,2.49)$ & N/A \\
\hline & El-Gilany and Hammad, 2010 [66] & $7.01(1.52,32.33)$ & N/A \\
\hline & Stepan et al., $2006[52]$ & $2.86(2.28,3.60)$ & N/A \\
\hline & van Wootten and Turner, 2002 [59] & $4.72(0.90,24.75)$ & $\mathrm{N} / \mathrm{A}$ \\
\hline & Mantakas and Farrell, 2010 [65] & $2.20(1.74,2.79)$ & $1.9(1.5,2.5)$ \\
\hline & Le Thai et al., 1992 [68] & $23.88(3.09,184.72)$ & N/A \\
\hline & Brennand et al., 2005 [71] & $3.76(2.34,6.03)$ & $3.73(2.41,5.05)$ \\
\hline & Crane et al., 2009 [44] & $1.86(1.47,2.36)$ & N/A \\
\hline & Sukalich et al., 2006 [50] & $1.78(1.29,2.46)$ & $1.6(1.2,2.0)$ \\
\hline & Jensen et al., 2003 [51] & $1.43(1.15,1.79)$ & $2.2(1.6-3.1)$ \\
\hline & Baeten et al., 2001 [23] & $1.95(1.84,2.07)$ & $2.1(1.9,2.3)$ \\
\hline & Driul et al., 2008 [56] & $2.58(1.07,6.19)$ & $2.58(1.08,6.21)$ \\
\hline & Roman et al., 2007 [57] & $3.11(2.28,4.22)$ & $3.1(2.2,4.3)$ \\
\hline & Sahu et al., 2007 [58] & N/A & N/A \\
\hline & Rode et al., $2005[33,60]$ & $1.9(1.53,2.32)$ & $1.8(1.4-2.2)$ \\
\hline & Langer et al., 2005 [63] & $1.89(1.43,2.50)$ & N/A \\
\hline & Total & $2.01(1.93,2.11)$ & $\mathrm{N} / \mathrm{A}$ \\
\hline \multirow{9}{*}{$\begin{array}{l}\text { Macrosomia } \\
\text { (birth weight } \\
\geq 4500 \mathrm{~g} \text { ) }\end{array}$} & Khashan and Kenny, 2009 [48] & $3.23(2.86,3.66)$ & $2.71(2.38,3.07)$ \\
\hline & Clausen et al., 2005 [55] & $3.72(1.86,7.41)$ & $4.3(1.5,12.1)$ \\
\hline & Mantakas and Farrell, 2010 [65] & $3.72(2.08,6.66)$ & $8.7(3.6-21.0)$ \\
\hline & Brennand et al., 2005 [71] & $2.94(1.40,6.16)$ & $2.95(1.87,4.03)$ \\
\hline & Crane et al., 2009 [44] & $1.87(1.28,2.73)$ & $\mathrm{N} / \mathrm{A}$ \\
\hline & Athukorala et al., 2010 [53] & $4.68(2.03,10.80)$ & $4.54(2.01,10.24)$ \\
\hline & Lumme et al., 1995 [62] & $2.23(1.45,3.45)$ & $1.8(1.1,2.8)$ \\
\hline & Jensen et al., 1999 [64] & $2.02(1.21,3.38)$ & $\mathrm{N} / \mathrm{A}$ \\
\hline & Total & $3.01(2.71,3.34)$ & $\mathrm{N} / \mathrm{A}$ \\
\hline
\end{tabular}


Meta-analysis

Statistics for each study

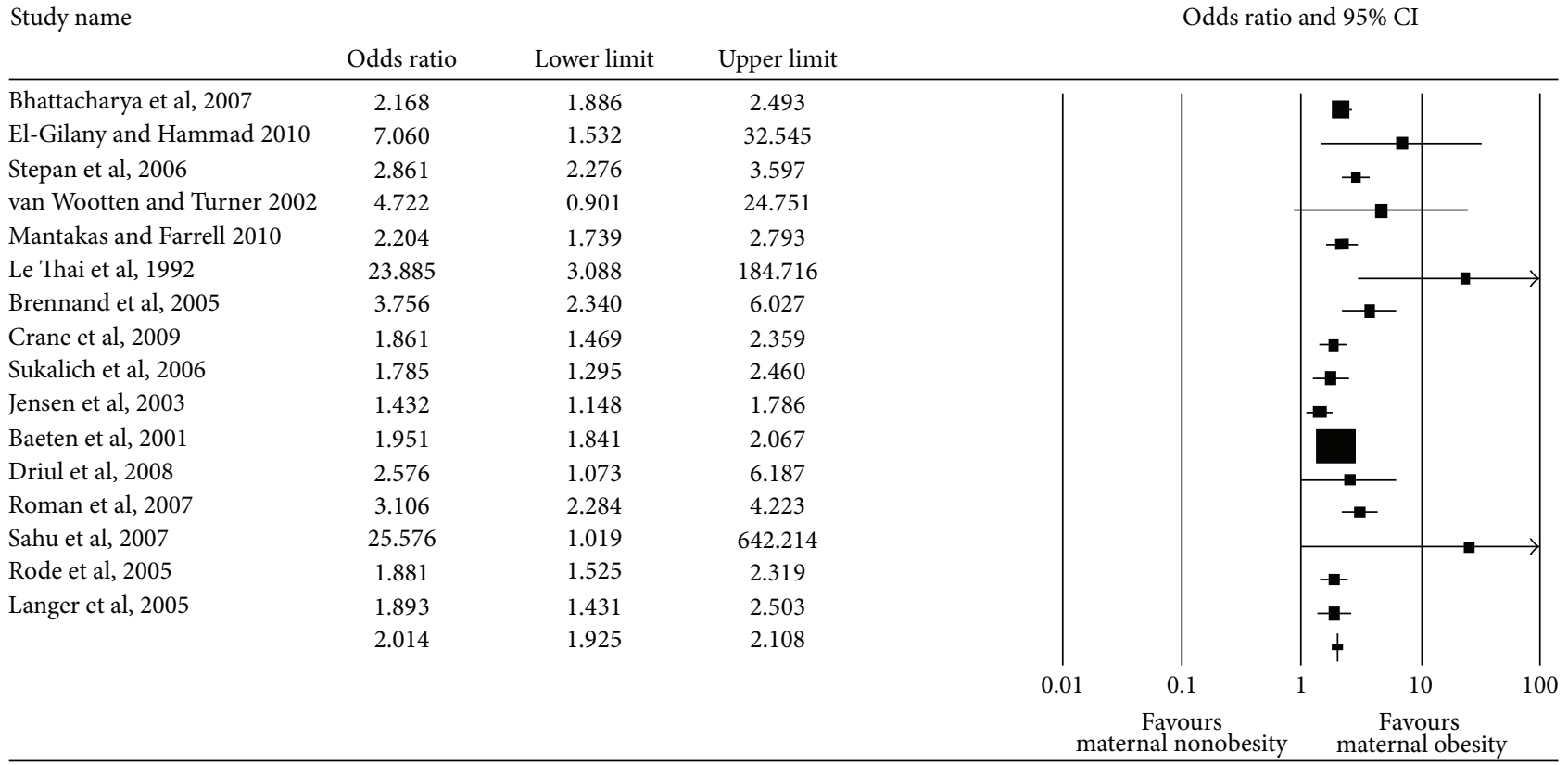

FIGURE 3: Forest plot for macrosomia (birth weight $\geq 4000 \mathrm{~g}$ ).

Meta-analysis

Statistics for each study

Study name

Odds ratio and 95\% CI

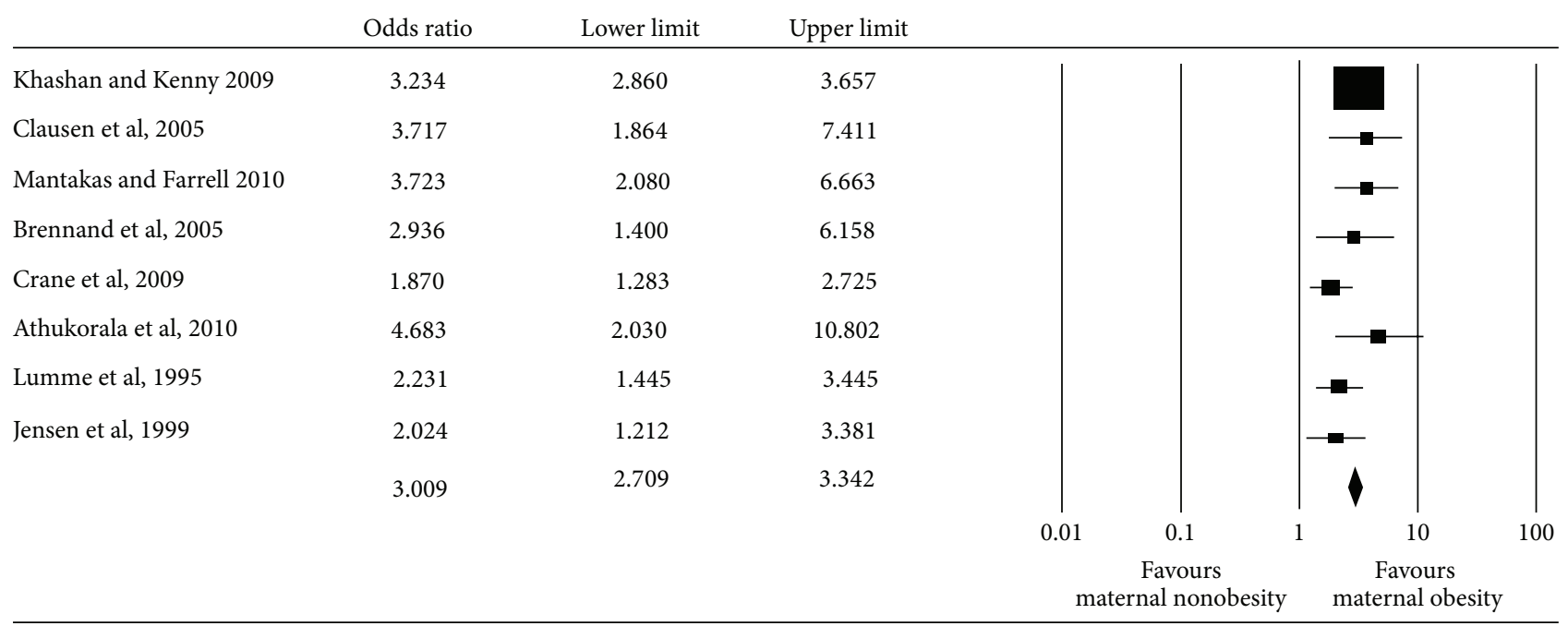

FIGURE 4: Forest plot for macrosomia (birth weight $\geq 4500 \mathrm{~g}$ ).

amount of heterogeneity that cannot be explained by chance alone. Sensitivity analysis showed that including only high quality studies decreased heterogeneity for LGA; the $I^{2}$ value improved to $0 \%$ from $97 \%$. Including only high quality studies for LGA gives an odds ratio of 2.54 (95\% CI 2.22, 2.92 ). As there was only one high quality study for macrosomia $\geq 4000 \mathrm{~g}$, a similar analysis could not be undertaken.
For macrosomia $\geq 4500 \mathrm{~g}$, the $I^{2}$ value worsened slightly, from $48 \%$ to $62 \%$.

\section{Conclusion}

This systematic review and meta-analysis confirms that maternal obesity is associated with fetal overgrowth. The 
odds of delivering an excessively large baby are increased: for large for gestational age infant ( $\geq 90$ th percentile) by $142 \%$, for birth weight $\geq 4000 \mathrm{~g}$ by $117 \%$, and for birth weight $\geq 4500 \mathrm{~g}$ by $277 \%$. Determinants of macrosomia have been studied extensively. Identified risk factors include maternal prepregnancy diabetes (adjusted OR 4.6, 95\% CI 2.57, 8.24), previous macrosomic birth (OR 3.1, 95\% CI 2.61, 3.74), postterm pregnancy greater than 42 weeks gestation (OR 3.1, 95\% CI 2.47, 3.86), maternal excess weight with BMI greater than 25 before pregnancy (OR 2.0, 95\% CI 1.72, 2.32), male infant gender (OR 1.9, 95\% CI 1.66, 2.21), gestational diabetes mellitus (OR 1.6, 95\% CI 1.26, 2.16), and nonsmoking (OR 1.4, 95\% CI 1.14, 1.82) [302]. Fetal growth is a complex biologic process that is regulated by both maternal and fetal factors including genes and environment. Maternal obesity likely contributes to macrosomia via mechanisms including increased insulin resistance (even in women who do not have diabetes) resulting in higher fetal glucose and insulin levels [309]. Placental lipases metabolize triglycerides in maternal blood, allowing free fatty acids to be transferred in excess to the growing fetus [310].

The sensitivity analysis suggested the importance of conducting well-designed high-quality studies. Of particular importance is ensuring that maternal weight and height are directly measured as early in pregnancy as possible. Data from a recent prospective cohort study found that pregnant women of all body masses under-report their prepregnancy weight when first trimester weight is used as a proxy which further substantiates the need for objective measurements [311]. The limitations of using either selfreported prepregnancy weight or first trimester weight as a surrogate for prepregnancy weight must be considered. Few women, however, will enter a different class of body mass on the basis of this potential misclassification bias.

The generalizability of the results should be interpreted with caution. The majority of the studies included in this review (including several national population-based cohorts) were completed in North America and Western Europe. Few studies examined the role of maternal obesity on fetal overgrowth in women from Africa, Asia, or South America. As there are fundamental differences in nutrition, socioeconomic and educational status, and prenatal/intrapartum care in these regions, results may or may not be applicable.

The results from this meta-analysis provide convincing evidence of the positive relationship between maternal obesity and fetal overgrowth. Clearly, optimization of weight prior to pregnancy is ideal; individual and public health measures should be in place to encourage women to have a normal body weight prior to pregnancy. Maternity and newborn care providers should be aware of the increased risk among obese women, encourage lifestyle modifications that decrease gestational weight gain, and manage abnormal glucose metabolism to optimize fetal growth. This is important to decrease both intrapartum complications and neonatal sequelae (such as birth trauma and hypoglycemia). Furthermore, optimal fetal growth contributes to in utero epigenetic programming that favours a healthy long-term weight trajectory and metabolic profile. The association between maternal obesity and fetal overgrowth may well represent the first opportunity through which obese mothers can modify the intergenerational obesity cycle and result in healthier, happier families.

\section{Conflict of Interests}

The authors declare that there is no conflict of interests regarding the publication of this paper.

\section{References}

[1] J. Bérard, P. Dufour, D. Vinatier et al., "Fetal macrosomia: risk factors and outcome. A study of the outcome concerning 100 cases $>4500$ g," European Journal of Obstetrics \& Gynecology and Reproductive Biology, vol. 77, no. 1, pp. 51-59, 1998.

[2] K. D. Gregory, O. A. Henry, E. Ramicone, L. S. Chan, and L. D. Platt, "Maternal and infant complications in high and normal weight infants by method of delivery," Obstetrics and Gynecology, vol. 92, no. 4 I, pp. 507-513, 1998.

[3] S. P. Chauhan, W. A. Grobman, R. A. Gherman et al., "Suspicion and treatment of the macrosomic fetus: a review," American Journal of Obstetrics \& Gynecology, vol. 193, no. 2, pp. 332-346, 2005.

[4] P. J. Surkan, C.-C. Hsieh, A. L. V. Johansson, P. W. Dickman, and S. Cnattingius, "Reasons for increasing trends in large for gestational age births," Obstetrics and Gynecology, vol. 104, no. 4, pp. 720-726, 2004.

[5] M. Khashu, G. Pelligra, S. Bhargava, and J. A. Smyth, Perinatal Morbidity in Macrosomic Infants, Pediatric Academy of Sciences, 2005.

[6] S. L. Boulet, H. M. Salihu, and G. R. Alexander, "Mode of delivery and birth outcomes of macrosomic infants," Journal of Obstetrics and Gynaecology, vol. 24, no. 6, pp. 622-629, 2004.

[7] D. J. Barker, "In utero programming of cardiovascular disease," Theriogenology, vol. 53, no. 2, pp. 555-574, 2000.

[8] D. J. P. Barker, A. R. Bull, C. Osmond, and S. J. Simmonds, "Fetal and placental size and risk of hypertension in adult life," British Medical Journal, vol. 301, no. 6746, pp. 259-262, 1990.

[9] P. M. Catalano and H. M. Ehrenberg, "The short- and longterm implications of maternal obesity on the mother and her offspring," BJOG: An International Journal of Obstetrics \& Gynaecolog, vol. 113, no. 10, pp. 1126-1133, 2006.

[10] D. Dabelea, R. L. Hanson, R. S. Lindsay et al., "Intrauterine exposure to diabetes conveys risks for type 2 diabetes and obesity: a study of discordant sibships," Diabetes, vol. 49 , no. 12, pp. 2208-2211, 2000.

[11] L. Dubois and M. Girard, "Early determinants of overweight at 4.5 years in a population-based longitudinal study," International Journal of Obesity, vol. 30, no. 4, pp. 610-617, 2006.

[12] M. W. Gillman, S. Rifas-Shiman, C. S. Berkey, A. E. Field, and G. A. Colditz, "Maternal gestational diabetes, birth weight, and adolescent obesity," Pediatrics, vol. 111, no. 3, pp. e221-e226, 2003.

[13] P. D. Gluckman, M. A. Hanson, C. Cooper, and K. L. Thornburg, "Effect of in utero and early-life conditions on adult health and disease," The New England Journal of Medicine, vol. 359, no. 1, pp. 61-73, 2008.

[14] R. C. Huang, V. Burke, J. P. Newnham et al., "Perinatal and childhood origins of cardiovascular disease," International Journal of Obesity, vol. 31, no. 2, pp. 236-244, 2007. 
[15] G. Moschonis, E. Grammatikaki, and Y. Manios, "Perinatal predictors of overweight at infancy and preschool childhood: the GENESIS study," International Journal of Obesity, vol. 32, no. 1, pp. 39-47, 2008.

[16] E. Oken, E. M. Taveras, K. P. Kleinman, J. W. Rich-Edwards, and M. W. Gillman, "Gestational weight gain and child adiposity at age 3 years," American Journal of Obstetrics \& Gynecology, vol. 196, no. 4, pp. 322-e1, 2007.

[17] T. J. Parsons, C. Power, and O. Manor, "Fetal and early life growth and body mass index from birth to early adulthood in 1958 British cohort: longitudinal," British Medical Journal, vol. 323, no. 7325, pp. 1331-1335, 2001.

[18] P. J. Salsberry and P. B. Reagan, "Dynamics of early childhood overweight," Pediatrics, vol. 116, no. 6, pp. 1329-1338, 2005.

[19] T. J. Wilkin, B. S. Metcalf, M. J. Murphy, J. Kirkby, A. N. Jeffery, and L. D. Voss, "The relative contributions of birth weight, weight change, and current weight to insulin resistance in contemporary 5-year-olds: the earlybird study," Diabetes, vol. 51, no. 12, pp. 3468-3472, 2002.

[20] B. H. Wrotniak, J. Shults, S. Butts, and N. Stettler, "Gestational weight gain and risk of overweight in the offspring at age $7 \mathrm{y}$ in a multicenter, multiethnic cohort study," The American Journal of Clinical Nutrition, vol. 87, no. 6, pp. 1818-1824, 2008.

[21] H. A. Abenhaim, R. A. Kinch, L. Morin, A. Benjamin, and R. Usher, "Effect of prepregnancy body mass index categories on obstetrical and neonatal outcomes," Archives of Gynecology and Obstetrics, vol. 275, no. 1, pp. 39-43, 2007.

[22] C. V. Ananth and S. W. Wen, "Trends in fetal growth among singleton gestations in the United States and Canada, 1985 through 1998," Seminars in Perinatology, vol. 26, no. 4, pp. 260 267, 2002.

[23] J. M. Baeten, E. A. Bukusi, and M. Lambe, "Pregnancy complications and outcomes among overweight and obese nulliparous women," American Journal of Public Health, vol. 91, no. 3, pp. 436-440, 2001.

[24] S. Bhattacharya, D. M. Campbell, and W. A. Liston, "Effect of Body Mass Index on pregnancy outcomes in nulliparous women delivering singleton babies," BMC Public Health, vol. 7, article 168, 2007.

[25] A. T. Bianco, S. W. Smilen, Y. Davis, S. Lopez, R. Lapinski, and C. J. Lockwood, "Pregnancy outcome and weight gain recommendations for the morbidly obese woman," Obstetrics and Gynecology, vol. 91, no. 1, pp. 97-102, 1998.

[26] M. Cedergren, "Maternal morbid obesity and the risk of adverse pregnancy outcome," Obstetrics \& Gynecology, vol. 103, no. 2, pp. 219-224, 2004.

[27] M. Cedergren, "Effects of gestational weight gain and body mass index on obstetric outcome in Sweden," International Journal of Gynecology and Obstetrics, vol. 93, no. 3, pp. 269-274, 2006.

[28] H. M. Ehrenberg, B. M. Mercer, and P. M. Catalano, "The influence of obesity and diabetes on the prevalence of macrosomia," The American Journal of Obstetrics and Gynecology, vol. 191, no. 3, pp. 964-968, 2004.

[29] D. M. Jensen, P. Ovesen, H. Beck-Nielsen et al., "Gestational weight gain and pregnancy outcomes in 481 obese glucosetolerant women," Diabetes Care, vol. 28, no. 9, pp. 2118-2122, 2005.

[30] G. C. Lu, D. J. Rouse, M. DuBard, S. Cliver, D. Kimberlin, and J. C. Hauth, "The effect of the increasing prevalence of maternal obesity on perinatal morbidity," The American Journal of Obstetrics and Gynecology, vol. 185, no. 4, pp. 845-849, 2001.
[31] R. Michlin, M. Oettinger, M. Odeh et al., "Maternal obesity and pregnancy outcome," Israel Medical Association Journal, vol. 2, no. 1, pp. 10-13, 2000.

[32] J. Ørskou, T. B. Henriksen, U. Kesmodel, and N. J. Secher, "Maternal characteristics and lifestyle factors and the risk of delivering high birth weight infants," Obstetrics and Gynecology, vol. 102, no. 1, pp. 115-120, 2003.

[33] L. Rode, L. Nilas, K. Wøjdemann, and A. Tabor, "Obesityrelated complications in Danish single cephalic term pregnancies," Obstetrics \& Gynecology, vol. 105, no. 3, pp. 537-542, 2005.

[34] T. J. Rosenberg, S. Garbers, W. Chavkin, and M. A. Chiasson, "Prepregnancy weight and adverse perinatal outcomes in an ethnically diverse population," Obstetrics and Gynecology, vol. 102, no. 5, pp. 1022-1027, 2003.

[35] T. J. Rosenberg, S. Garbers, H. Lipkind, and M. A. Chiasson, "Maternal obesity and diabetes as risk factors for adverse pregnancy outcomes: differences among $4 \mathrm{racial} / \mathrm{ethnic}$ groups," American Journal of Public Health, vol. 95, no. 9, pp. 1545-1551, 2005.

[36] R. K. Sarkar, S. M. Cooley, J. C. Donnelly, T. Walsh, C. Collins, and M. P. Geary, "The incidence and impact of increased body mass index on maternal and fetal morbidity in the lowrisk primigravid population," Journal of Maternal-Fetal and Neonatal Medicine, vol. 20, no. 12, pp. 879-883, 2007.

[37] N. J. Sebire, M. Jolly, J. P. Harris et al., "Maternal obesity and pregnancy outcome: a study of 287213 pregnancies in London," International Journal of Obesity, vol. 25, no. 8, pp. 1175-1182, 2001.

[38] N. E. Stotland, L. M. Hopkins, and A. B. Caughey, "Gestational weight gain, macrosomia, and risk of cesarean birth in nondiabetic nulliparas," Obstetrics and Gynecology, vol. 104, no. 4, pp. 671-677, 2004

[39] J. L. Weiss, F. D. Malone, D. Emig et al., "Obesity, obstetric complications and cesarean delivery rate-a population-based screening study," The American Journal of Obstetrics and Gynecology, vol. 190, no. 4, pp. 1091-1097, 2004.

[40] Z. M. Ferraro, N. Barrowman, D. Prud'homme et al., "Excessive gestational weight gain predicts large for gestational age neonates independent of maternal body mass index," Journal of Maternal-Fetal and Neonatal Medicine, vol. 25, no. 5, pp. 538542, 2012.

[41] N. Heslehurst, H. Simpson, L. J. Ells et al., "The impact of maternal BMI status on pregnancy outcomes with immediate short-term obstetric resource implications: a meta-analysis," Obesity Reviews, vol. 9, no. 6, pp. 635-683, 2008.

[42] G. L. Hoff, J. Cai, F. A. Okah, and P. C. Dew, "Pre-pregnancy overweight status between successive pregnancies and pregnancy outcomes," Journal of Women's Health, vol. 18, no. 9, pp. 1413-1417, 2009.

[43] H. M. Salihu, A. K. Mbah, A. P. Alio, J. L. Kornosky, K. Bruder, and V. Belogolovkin, "Success of programming fetal growth phenotypes among obese women," Obstetrics and Gynecology, vol. 114, no. 2, pp. 333-339, 2009.

[44] J. M. G. Crane, J. White, P. Murphy, L. Burrage, and D. Hutchens, "The effect of gestational weight gain by body mass index on maternal and neonatal outcomes," Journal of Obstetrics and Gynaecology Canada: JOGC, vol. 31, no. 1, pp. 28-35, 2009.

[45] T. Y. Leung, T. N. Leung, D. S. Sahota et al., "Trends in maternal obesity and associated risks of adverse pregnancy outcomes in a population of Chinese women," BJOG: An International Journal of Obstetrics and Gynaecology, vol. 115, no. 12, pp. 1529-1537, 2008 . 
[46] E. A. Nohr, M. Vaeth, J. L. Baker, T. I. A. Sørensen, J. Olsen, and K. M. Rasmussen, "Combined associations of prepregnancy body mass index and gestational weight gain with the outcome of pregnancy," The American Journal of Clinical Nutrition, vol. 88, no. 6, pp. 1705-1759, 2008.

[47] E. A. Nohr, M. Vaeth, J. L. Baker, T. I. A. Sørensen, J. Olsen, and K. M. Rasmussen, "Combines associtions of prepregnancy body mass index and gestational weight gain with the outcome of pregnancy," The American Journal of Clinical Nutrition, vol. 88, no. 6, pp. 1705-1759, 2008.

[48] A. S. Khashan and L. C. Kenny, "The effects of maternal body mass index on pregnancy outcome," European Journal of Epidemiology, vol. 24, no. 11, pp. 697-705, 2009.

[49] D. Getahun, C. V. Ananth, M. R. Peltier, H. M. Salihu, and W. E. Scorza, "Changes in prepregnancy body mass index between the first and second pregnancies and risk of large-for-gestationalage birth," American Journal of Obstetrics and Gynecology, vol. 196, no. 6, pp. 530.e1-530.e8, 2007.

[50] S. Sukalich, M. J. Mingione, and J. C. Glantz, "Obstetric outcomes in overweight and obese adolescents," American Journal of Obstetrics \& Gynecology, vol. 195, no. 3, pp. 851-855, 2006.

[51] D. M. Jensen, P. Damm, B. Sørensen et al., "Pregnancy outcome and prepregnancy body mass index in 2459 glucose-tolerant Danish women," The American Journal of Obstetrics and Gynecology, vol. 189, no. 1, pp. 239-244, 2003.

[52] H. Stepan, S. Scheithauer, N. Dornhöfer, T. Krämer, and R. Faber, "Obesity as an obstetric risk factor: does it matter in a perinatal center?” Obesity, vol. 14, no. 5, pp. 770-773, 2006.

[53] C. Athukorala, A. R. Rumbold, K. J. Willson, and C. A. Crowther, "The risk of adverse pregnancy outcomes in women who are overweight or obese," BMC Pregnancy and Childbirth, vol. 10, article 56, 2010.

[54] H. Narchi and A. Skinner, "Overweight and obesity in pregnancy do not adversely affect neonatal outcomes: new evidence," Journal of Obstetrics and Gynaecology, vol. 30, no. 7, pp. 679-686, 2010.

[55] T. Clausen, T. K. Burski, N. Øyen, K. Godang, J. Bollerslev, and T. Henriksen, "Maternal anthropometric and metabolic factors in the first half of pregnancy and risk of neonatal macrosomia in term pregnancies. A prospective study," European Journal of Endocrinology, vol. 153, no. 6, pp. 887-894, 2005.

[56] L. Driul, G. Cacciaguerra, A. Citossi, M. D. Martina, L. Peressini, and D. Marchesoni, "Prepregnancy body mass index and adverse pregnancy outcomes," Archives of Gynecology and Obstetrics, vol. 278, no. 1, pp. 23-26, 2008.

[57] H. Roman, P. Y. Robillard, T. C. Hulsey et al., "Obstetrical and neonatal outcomes in obese women," West Indian Medical Journal, vol. 56, no. 5, pp. 421-426, 2007.

[58] M. T. Sahu, A. Agarwal, V. Das, and A. Pandey, "Impact of maternal body mass index on obstetric outcome," Journal of Obstetrics and Gynaecology Research, vol. 33, no. 5, pp. 655-659, 2007.

[59] W. van Wootten and R. E. Turner, "Macrosomia in neonates of mothers with gestational diabetes is associated with body mass index and previous gestational diabetes," Journal of the American Dietetic Association, vol. 102, no. 2, pp. 241-243, 2002.

[60] L. Rode, L. Nilas, K. Wøjdemann, and A. Tabor, "Obesityrelated complications in Danish single cephalic term pregnancies," Obstetrics and Gynecology, vol. 105, no. 3, pp. 537-542, 2005.

[61] E. F. Magann, D. A. Doherty, S. P. Chauhan, J. M. Klimpel, S. D. Huff, and J. C. Morrison, "Pregnancy, obesity, gestational weight gain, and parity as predictors of peripartum complications," Archives of Gynecology and Obstetrics, vol. 284, no. 4, pp. 827836, 2011.

[62] R. Lumme, P. Rantakallio, A.-L. Hartikainen, and M.-R. Jarvelin, "Pre-pregnancy weight and its relation to pregnancy outcome," Journal of Obstetrics and Gynaecology, vol. 15, no. 2, pp. 69-75, 1995.

[63] O. Langer, Y. Yogev, E. M. J. Xenakis, and L. Brustman, "Overweight and obese in gestational diabetes: the impact on pregnancy outcome," American Journal of Obstetrics and Gynecology, vol. 192, no. 6, pp. 1768-1776, 2005.

[64] H. Jensen, A. O. Agger, and K. L. Rasmussen, "The influence of prepregnancy body mass index on labor complications," Acta Obstetricia et Gynecologica Scandinavica, vol. 78, no. 9, pp. 799802, 1999.

[65] A. Mantakas and T. Farrell, "The influence of increasing BMI in nulliparous women on pregnancy outcome," European Journal of Obstetrics Gynecology and Reproductive Biology, vol. 153, no. 1, pp. 43-46, 2010.

[66] A.-H. El-Gilany and S. Hammad, "Body mass index and obstetric outcomes in pregnant in Saudi Arabia: a prospective cohort study," Annals of Saudi Medicine, vol. 30, no. 5, pp. 376421,2010

[67] L. M. Bodnar, A. M. Siega-Riz, H. N. Simhan, K. P. Himes, and B. Abrams, "Severe obesity, gestational weight gain, and adverse birth outcomes," The American Journal of Clinical Nutrition, vol. 91, no. 6, pp. 1642-1648, 2010.

[68] N. Le Thai, G. Lefebvre, V. Stella et al., "Pregnancy and obesity. A study of 140 cases and controls," Journal de Gynecologie Obstetrique et Biologie de la Reproduction, vol. 21, no. 5, pp. 563$567,1992$.

[69] M. Voigt, S. Straube, M. Zygmunt, B. Krafczyk, K. T. M. Schneider, and V. Briese, "Obesity and pregnancy-a risk profile," Zeitschrift für Geburtshilfe und Neonatologie, vol. 212, no. 6, pp. 201-205, 2008.

[70] M. Voigt, M. Zygmunt, W. Henrich, S. Straube, M. Carstensen, and V. Briese, "Analysis of subgroup of pregnant women in Germany 16th communication: morbid obesity: pregnancy risks, birth risks and status of the newborn," Geburtshilfe und Frauenheilkunde, vol. 68, no. 8, pp. 794-800, 2008.

[71] E. A. Brennand, D. Dannenbaum, and N. D. Willows, "Pregnancy outcomes of First Nations women in relation to pregravid weight and pregnancy weight gain," Journal of Obstetrics and Gynaecology Canada: JOGC, vol. 27, no. 10, pp. 936-944, 2005.

[72] G. A. Wells, B. Shea, D. O'Connell et al., "The Newcastle-Ottawa Quality Assessment Scale (NOS) for assessing the quality of nonrandomized studies in meta-analysis," 2010, http://www .ohri.ca/programs/clinical_epidemiology/oxford.asp.

[73] R. DerSimonian and N. Laird, "Meta-analysis in clinical trials," Controlled Clinical Trials, vol. 7, no. 3, pp. 177-188, 1986.

[74] L. Rode, H. K. Hegaard, H. Kjærgaard, L. F. Møller, A. Tabor, and B. Ottesen, "Association between maternal weight gain and birth weight," Obstetrics and Gynecology, vol. 109, no. 6, pp. 1309-1315, 2007.

[75] M. I. Cedergren, "Non-elective caesarean delivery due to ineffective uterine contractility or due to obstructed labour in relation to maternal body mass index," European Journal of Obstetrics Gynecology and Reproductive Biology, vol. 145, no. 2, pp. 163-166, 2009.

[76] J. C. Madan, J. M. Davis, W. Y. Craig et al., "Maternal obesity and markers of inflammation in pregnancy," Cytokine, vol. 47, no. 1 , pp. 61-64, 2009. 
[77] J. S. Dashe, D. D. McIntire, and D. M. Twickler, "Effect of maternal obesity on the ultrasound detection of anomalous fetuses," Obstetrics and Gynecology, vol. 113, no. 5, pp. 1001-1007, 2009.

[78] C. Schrauwers and G. Dekker, "Maternal and perinatal outcome in obese pregnant patients," Journal of Maternal-Fetal and Neonatal Medicine, vol. 22, no. 3, pp. 218-226, 2009.

[79] A. A. Mamun, M. O'Callaghan, L. Callaway, G. Williams, J. Najman, and D. A. Lawlor, "Associations of gestational weight gain with offspring body mass index and blood pressure at 21 years of ageevidence from a birth cohort study," Circulation, vol. 119, no. 13, pp. 1720-1727, 2009.

[80] N. Voldner, K. F. Frøslie, L. A. H. Haakstad, K. Bø, and T. Henriksen, "Birth complications, overweight, and physical inactivity," Acta Obstetricia et Gynecologica Scandinavica, vol. 88, no. 5, pp. 550-555, 2009.

[81] S. Y. Chu, W. M. Callaghan, C. L. Bish, and D. D’Angelo, "Gestational weight gain by body mass index among US women delivering live births, 2004-2005: fueling future obesity," The American Journal of Obstetrics and Gynecology, vol. 200, no. 3, pp. 271.e1-271.e7, 2009.

[82] S. J. Herring, E. Oken, J. Haines et al., "Misperceived prepregnancy body weight status predicts excessive gestational weight gain: findings from a US cohort study," BMC Pregnancy and Childbirth, vol. 8, article 54, 2008.

[83] A. Ben-Haroush, E. Hadar, R. Chen, M. Hod, and Y. Yogev, "Maternal obesity is a major risk factor for large-for-gestationalinfants in pregnancies complicated by gestational diabetes," Archives of Gynecology and Obstetrics, vol. 279, no. 4, pp. 539543, 2009.

[84] N. Heslehurst, H. Simpson, L. J. Ells et al., "The impact of maternal BMI status on pregnancy outcomes with immediate short-term obstetric resource implications: a meta-analysis," Obesity Reviews, vol. 9, no. 6, pp. 635-683, 2008.

[85] S. Y. Chu, S. Y. Kim, and C. L. Bish, "Prepregnancy obesity prevalence in the United States, 2004-2005," Maternal and Child Health Journal, vol. 13, no. 5, pp. 614-620, 2009.

[86] J. Naftalin and S. Paterson-Brown, "A pilot study exploring the impact of maternal age and raised body mass index on caesarean section rates," Journal of Obstetrics and Gynaecology, vol. 28 , no. 4, pp. 394-397, 2008.

[87] A. Ray, A. Hildreth, and U. I. Esen, "Morbid obesity and intrapartum care," Journal of Obstetrics \& Gynaecology, vol. 28, no. 3, pp. 301-304, 2008.

[88] R. B. Ness, J. Zhang, D. Bass, and M. A. Klebanoff, "Interactions between smoking and weight in pregnancies complicated by preeclampsia and small-for-gestational-age birth," American Journal of Epidemiology, vol. 168, no. 4, pp. 427-433, 2008.

[89] F. C. Denison, J. Price, C. Graham, S. Wild, and W. A. Liston, "Maternal obesity, length of gestation, risk of postdates pregnancy and spontaneous onset of labour at term," BJOG, vol. 115, no. 6, pp. 720-725, 2008.

[90] S. Y. Chu, D. J. Bachman, W. M. Callaghan et al., "Association between obesity during pregnancy and increased use of health care," The New England Journal of Medicine, vol. 358, no. 14, pp. 1444-1453, 2008.

[91] V. Briese, M. Voigt, M. Hermanussen, and U. Wittwer-Backofen, "Morbid obesity: pregnancy risks, birth risks and status of the newborn," HOMO-Journal of Comparative Human Biology, vol. 61, no. 1, pp. 64-72, 2010.
[92] A. M. Kerrigan and C. Kingdon, "Maternal obesity and pregnancy: a retrospective study," Midwifery, vol. 26, no. 1, pp. 138146, 2010.

[93] E. A. Nohr, M. Vaeth, J. L. Baker, T. I. A. Sorenson, J. Olsen, and K. M. Rasmussen, "Pregnancy outcomes related to gestational weight gain in women defined by their body mass index, parity, height, and smoking status," The American Journal of Clinical Nutrition, vol. 90, pp. 1288-1294, 2009.

[94] Y. Yogev and O. Langer, "Pregnancy outcome in obese and morbidly obese gestational diabetic women," European Journal of Obstetrics Gynecology and Reproductive Biology, vol. 137, no. 1, pp. 21-26, 2008.

[95] C. Kabali and M. M. Werler, "Pre-pregnant body mass index, weight gain and the risk of delivering large babies among non-diabetic mothers," International Journal of Gynecology \& Obstetrics, vol. 97, no. 2, pp. 100-104, 2007.

[96] E. Villamor and S. Cnattingius, "Interpregnancy weight change and risk of adverse pregnancy outcomes: a population-based study," The Lancet, vol. 368, no. 9542, pp. 1164-1170, 2006.

[97] G. Barau, P.-Y. Robillard, T. C. Hulsey et al., "Linear association between maternal pre-pregnancy body mass index and risk of caesarean section in term deliveries," BJOG: An International Journal of Obstetrics \& Gynaecology, vol. 113, no. 10, pp. 11731177, 2006.

[98] M. I. Cedergren, "Maternal morbid obesity and the risk of adverse pregnancy outcome," Obstetrics and Gynecology, vol. 103, no. 2, pp. 219-224, 2004.

[99] S. Škrablin, V. Banović, and I. Kuvačić, "Morbid maternal obesity and pregnancy," International Journal of Gynecology and Obstetrics, vol. 85, no. 1, pp. 40-41, 2004.

[100] L. K. Callaway, J. B. Prins, A. M. Chang, and H. D. McIntyre, "The prevalence and impact of overweight and obesity in an Australian obstetrics population," Medical Journal of Australia, vol. 184, no. 2, pp. 56-59, 2006.

[101] Y. Banda, V. Chapman, R. L. Goldenberg, B. H. Chi, S. H. Vermund, and J. S. A. Stringer, "Influence of body mass index on pregnancy outcomes among HIV-infected and HIV-uninfected Zambian women," Tropical Medicine and International Health, vol. 12, no. 7, pp. 856-861, 2007.

[102] M. Murakami, M. Ohmichi, T. Takahashi et al., "Prepregnancy body mass index as an important predictor of perinatal outcomes in Japanese," Archives of Gynecology and Obstetrics, vol. 271, no. 4, pp. 311-315, 2005.

[103] H. M. Ehrenberg, C. P. Durnwald, P. Catalano, and B. M. Mercer, "The influence of obesity and diabetes on the risk of cesarean delivery," The American Journal of Obstetrics and Gynecology, vol. 191, no. 3, pp. 969-974, 2004.

[104] T. S. Usha Kiran, S. Hemmadi, J. Bethel, and J. Evans, "Outcome of pregnancy in a woman with an increased body mass index," BJOG: An International Journal of Obstetrics and Gynaecology, vol. 112, no. 6, pp. 768-772, 2005.

[105] U. M. Schaefer-Graf, J. Pawliczak, D. Passow et al., "Birth weight and parental BMI predict overweight in children from mothers with gestational diabetes," Diabetes Care, vol. 28, no. 7, pp. 1745$1750,2005$.

[106] D. A. Doherty, E. F. Magann, J. Francis, J. C. Morrison, and J. P. Newnham, "Pre-pregnancy body mass index and pregnancy outcomes,' International Journal of Gynecology and Obstetrics, vol. 95, no. 3, pp. 242-247, 2006.

[107] Y. S. Thornton, C. Smarkola, S. M. Kopacz, and S. B. Ishoof, "Perinatal outcomes in nutritionally monitored obese pregnant 
women: a randomized clinical trial," Journal of the National Medical Association, vol. 101, no. 6, pp. 569-577, 2009.

[108] H. Aly, T. Hammad, A. Nada, M. Mohamed, S. Bathgate, and A. El-Mohandes, "Maternal obesity, associated complications and risk of prematurity," Journal of Perinatology, vol. 30, no. 7, pp. 447-451, 2010.

[109] D. A. Lawlor, A. Fraser, R. S. Lindsay et al., "Association of existing diabetes, gestational diabetes and glycosuria in pregnancy with macrosomia and offspring body mass index, waist and fat mass in later childhood: findings from a prospective pregnancy cohort," Diabetologia, vol. 53, no. 1, pp. 89-97, 2010.

[110] E. Jarvie and J. E. Ramsay, "Obstetric management of obesity in pregnancy," Seminars in Fetal and Neonatal Medicine, vol. 15, no. 2, pp. 83-88, 2010.

[111] C. M. Baron, L. G. Girling, A. L. Mathieson et al., "Obstetrical and neonatal outcomes in obese parturients," Journal of Maternal-Fetal \& Neonatal Medicine, vol. 23, no. 8, pp. 906-913, 2010.

[112] K. Raatikainen, N. Heiskanen, and S. Heinonen, "Transition from overweight to obesity worsens pregnancy outcome in a BMI-dependent manner," Obesity, vol. 14, no. 1, pp. 165-171, 2006.

[113] E. T. Rhodes, D. B. Pawlak, T. C. Takoudes et al., "Effects of a low-glycemic load diet in overweight and obese pregnant women: a pilot randomized controlled trial," The American Journal of Clinical Nutrition, vol. 92, no. 6, pp. 1306-1315, 2010.

[114] M. C. Dennedy and F. Dunne, "The maternal and fetal impacts of obesity and gestational diabetes on pregnancy outcome," Best Practice and Research: Clinical Endocrinology and Metabolism, vol. 24, no. 4, pp. 573-589, 2010.

[115] A. Lapolla, M. Bonomo, M. G. Dalfra et al., "Prepregnancy BMI influences maternal and fetal outcomes in women with isolated gestational hyperglycaemia: a multicentre study," Diabetes and Metabolism, vol. 36, no. 4, pp. 265-270, 2010.

[116] M. Knight, J. J. Kurinczuk, P. Spark, and P. Brocklehurst, "Extreme obesity in pregnancy in the United Kingdom," Obstetrics and Gynecology, vol. 115, no. 5, pp. 989-997, 2010.

[117] M. C. Alanis, W. H. Goodnight, E. G. Hill, C. J. Robinson, M. S. Villers, and D. D. Johnson, "Maternal super-obesity (body mass index $\geq 50$ ) and adverse pregnancy outcomes," Acta Obstetricia et Gynecologica Scandinavica, vol. 89, no. 7, pp. 924-930, 2010.

[118] HAPO Study Cooperative Research Group, "Hyperglycaemia and Adverse Pregnancy Outcome (HAPO) Study: associations with maternal body mass index," BJOG, vol. 117, no. 5, pp. 575584, 2010.

[119] M. S. Hauger, L. Gibbons, T. Vik, and J. M. Belizán, "Prepregnancy weight status and the risk of adverse pregnancy outcome," Acta Obstetricia et Gynecologica Scandinavica, vol. 87, no. 9, pp. 953-959, 2008.

[120] T. O. Scholl, M. L. Hediger, J. I. Schall, I. G. Ances, and W. K. Smith, "Gestational weight gain, pregnancy outcome, and postpartum weight retention," Obstetrics and Gynecology, vol. 86, no. 3, pp. 423-427, 1995.

[121] H. C. Jang, N. H. Cho, Y.-K. Min, I. K. Han, K. B. Jung, and B. E. Metzger, "Increased macrosomia and perinatal morbidity independent of maternal obesity and advanced age in Korean women with GDM,' Diabetes Care, vol. 20, no. 10, pp. 1582-1588, 1997.

[122] S. Cnattingius, R. Bergström, L. Lipworth, and M. S. Kramer, "Prepregnancy weight and the risk of adverse pregnancy outcomes," The New England Journal of Medicine, vol. 338, no. 3, pp. 147-152, 1998.
[123] H. Wolfe, "High prepregnancy body-mass index-a maternalfetal risk factor," The New England Journal of Medicine, vol. 338, no. 3, pp. 191-192, 1998.

[124] D. Ogunyemi, S. Hullett, J. Leeper, and A. Risk, "Prepregnancy body mass index, weight gain during pregnancy, and perinatal outcome in a rural black population," The Journal of MaternalFetal Medicine, vol. 7, pp. 190-193, 1998.

[125] F. F. Lauszus, J. Paludan, and J. G. Klebe, "Birthweight in women with potential gestational diabetes mellitus-an effect of obesity rather than glucose intolerance?" Acta Obstetricia et Gynecologica Scandinavica, vol. 78, no. 6, pp. 520-525, 1999.

[126] A. S. Kumari, "Pregnancy outcome in women with morbid obesity," International Journal of Gynecology and Obstetrics, vol. 73, no. 2, pp. 101-107, 2001.

[127] J. M. Wojcicki, N. A. Hessol, M. B. Heyman, and E. FuentesAfflick, "Risk factors for macrosomia in infants born to Latina women," Journal of Perinatology, vol. 28, no. 11, pp. 743-749, 2008.

[128] Y. Yogev, O. Langer, E. M. J. Xenakis, and B. Rosenn, “The association between glucose challenge test, obesity and pregnancy outcome in 6390 non-diabetic women," Journal of MaternalFetal and Neonatal Medicine, vol. 17, no. 1, pp. 29-34, 2005.

[129] L. E. Edwards, W. L. Hellerstedt, I. R. Alton, M. Story, and J. H. Himes, "Pregnancy complications and birth outcomes in obese and normal-weight women: effects of gestational weight change," Obstetrics \& Gynecology, vol. 87, no. 3, pp. 389-394, 1996.

[130] D. W. Kiel, E. A. Dodson, R. Artal, T. K. Boehmer, and T. L. Leet, "Gestational weight gain and pregnancy outcomes in obese women: how much is enough?" Obstetrics and Gynecology, vol. 110, no. 4, pp. 752-758, 2007.

[131] P. M. Dietz, W. M. Callaghan, M. E. Cogswell, B. Morrow, C. Ferre, and L. A. Schieve, "Combined effects of prepregnancy body mass index and weight gain during pregnancy on the risk of preterm delivery," Epidemiology, vol. 17, no. 2, pp. 170-177, 2006.

[132] M. C. Jolly, N. J. Sebire, J. P. Harris, L. Regan, and S. Robinson, "Risk factors for macrosomia and its clinical consequences: a study of 350,311 pregnancies," European Journal of Obstetrics Gynecology and Reproductive Biology, vol. 111, no. 1, pp. 9-14, 2003.

[133] N. Voldner, K. F. Frøslie, K. Bø et al., "Modifiable determinants of fetal macrosomia: role of lifestyle-related factors," Acta Obstetricia et Gynecologica Scandinavica, vol. 87, no. 4, pp. 423429, 2008.

[134] U. M. Schaefer-Graf, R. Heuer, Ö. Kilavuz, A. Pandura, W. Henrich, and K. Vetter, "Maternal obesity not maternal glucose values correlates best with high rates of fetal macrosomia in pregnancies complicated by gestational diabetes," Journal of Perinatal Medicine, vol. 30, no. 4, pp. 313-321, 2002.

[135] G. A. Ramos and A. B. Caughey, "The interrelationship between ethnicity and obesity on obstetric outcomes," American Journal of Obstetrics \& Gynecology, vol. 193, no. 3, pp. 1089-1093, 2005.

[136] A. H. Balen and R. A. Anderson, "Impact of obesity on female reproductive health: British fertility society, policy and practice guidelines," Human Fertility, vol. 10, no. 4, pp. 195-206, 2007.

[137] E. A. McCarthy, B. J. G. Strauss, S. P. Walker, and M. Permezel, "Determination of maternal body composition in pregnancy and its relevance to perinatal outcomes," Obstetrical and Gynecological Survey, vol. 59, no. 10, pp. 731-742, 2004. 
[138] R. C. Whitaker, "Predicting preschooler obesity at birth: the role of maternal obesity in early pregnancy," Pediatrics, vol. 114, no. 1, pp. e29-e36, 2004.

[139] R. L. Bergmann, R. Richter, K. E. Bergmann, A. Plagemann, M. Brauer, and J. W. Dudenhausen, "Secular trends in neonatal macrosomia in Berlin: Influences of potential determinants," Paediatric and Perinatal Epidemiology, vol. 17, no. 3, pp. 244249, 2003.

[140] J. Brynhildsen, A. Sydsjö, K. Ekholm-Selling, and A. Josefsson, "The importance of maternal BMI on infant's birth weight in four BMI groups for the period 1978-2001," Acta Obstetricia et Gynecologica Scandinavica, vol. 88, no. 4, pp. 391-396, 2009.

[141] N. Heslehurst, R. Lang, J. Rankin, J. R. Wilkinson, and C. D. Summerbell, "Obesity in pregnancy: a study of the impact of maternal obesity on NHS maternity services," BJOG, vol. 114, no. 3, pp. 334-342, 2007.

[142] E. A. Reece, "Perspectives on obesity, pregnancy and birth outcomes in the United States: the scope of the problem," American Journal of Obstetrics and Gynecology, vol. 198, no. 1, pp. 23-27, 2008.

[143] R. May, "Prepregnancy weight, inappropriate gestational weight gain, and smoking: relationships to birth weight," American Journal of Human Biology, vol. 19, no. 3, pp. 305-310, 2007.

[144] A. B. Caughey, "Obesity, weight loss, and pregnancy outcomes," The Lancet, vol. 368, no. 9542, pp. 1136-1138, 2006.

[145] J. A. Hutcheon, R. W. Platt, S. J. Meltzer, and G. M. Egeland, "Is birth weight modified during pregnancy? Using sibling differences to understand the impact of blood glucose, obesity, and maternal weight gain in gestational diabetes," American Journal of Obstetrics and Gynecology, vol. 195, no. 2, pp. 488494, 2006.

[146] C. Mazouni, G. Porcu, E. Cohen-Solal et al., "Maternal and anthropomorphic risk factors for shoulder dystocia," Acta Obstetricia et Gynecologica Scandinavica, vol. 85, no. 5, pp. 567570, 2006.

[147] D. A. Lawlor, N. J. Timpson, R. M. Harbord et al., "Exploring the developmental overnutrition hypothesis using parentaloffspring associations and FTO as an instrumental variable," PLoS Medicine, vol. 5, no. 3, article e33, 2008.

[148] T. K. Young, B. Woodmansee, and V. M. Parisi, "Factors that are associated with cesarean delivery in a large private practice: the importance of prepregnancy body mass index and weight gain," American Journal of Obstetrics and Gynecology, vol. 187, no. 2, pp. 312-320, 2002.

[149] A. Pathi, U. Esen, and A. Hildreth, "A comparison of complications of pregnancy and delivery in morbidly obese and nonobese women," Journal of Obstetrics and Gynaecology, vol. 26, no. 6, pp. 527-530, 2006.

[150] D. A. Doherty, E. F. Magann, J. Francis, J. C. Morrison, and J. P. Newnham, "Pre-pregnancy body mass index and pregnancy outcomes," International Journal of Gynecology \& Obstetrics, vol. 95, no. 3, pp. 242-247, 2006.

[151] D. A. Lawlor, G. D. Smith, M. O'Callaghan et al., "Epidemiologic evidence for the fetal overnutrition hypothesis: findings from the Mater-University study of pregnancy and its outcomes," American Journal of Epidemiology, vol. 165, no. 4, pp. 418-424, 2007.

[152] V. Tomić, K. Bosnjak, B. Petrov, M. Dikić, and D. Knezević, "Macrosomic births at Mostar Clinical Hospital: a 2-year review," Bosnian Journal of Basic Medical Sciences, vol. 7, no. 3, pp. 271-274, 2007.
[153] I. Guelinckx, R. Devlieger, K. Beckers, and G. Vansant, "Maternal obesity: pregnancy complications, gestational weight gain and nutrition," Obesity Reviews, vol. 9, no. 2, pp. 140-150, 2008.

[154] A.-M. Siega-Riz and B. Laraia, "The implications of maternal overweight and obesity on the course of pregnancy and birth outcomes," Maternal and Child Health Journal, vol. 10, no. 7, pp. S153-S156, 2006.

[155] S. A. Lederman and A. Paxton, "Maternal reporting of prepregnancy weight and birth outcome: consistency and completeness compared with the clinical record," Maternal and Child Health Journal, vol. 2, no. 2, pp. 123-126, 1998.

[156] S. C. Gorber, M. Tremblay, D. Moher, and B. Gorber, "A comparison of direct vs. self-report measures for assessing height, weight and body mass index: a systematic review," Obesity Reviews, vol. 8, no. 4, pp. 307-326, 2007.

[157] J. L. Engstrom, S. A. Paterson, A. Doherty, M. Trabulsi, and K. L. Speer, "Accuracy of self-reported height and weight in women: an integrative review of the literature," Journal of Midwifery and Women's Health, vol. 48, no. 5, pp. 338-345, 2003.

[158] M. I. Cedergren, "Optimal gestational weight gain for body mass index categories," Obstetrics and Gynecology, vol. 110, no. 4, pp. 759-764, 2007.

[159] I. O. Frederick, M. A. Williams, A. E. Sales, D. P. Martin, and M. Killien, "Pre-pregnancy body mass index, gestational weight gain, and other maternal characteristics in relation to infant birth weight," Maternal and Child Health Journal, vol. 12, no. 5, pp. 557-567, 2008.

[160] T. Clausen, N. Øyen, and T. Henriksen, "Pregnancy complications by overweight and residential area. A prospective study of an urban Norwegian cohort," Acta Obstetricia et Gynecologica Scandinavica, vol. 85, no. 5, pp. 526-533, 2006.

[161] H. Robinson, S. Tkatch, D. C. Mayes, N. Bott, and N. Okun, "Is maternal obesity a predictor of shoulder dystocia?" Obstetrics and Gynecology, vol. 101, no. 1, pp. 24-27, 2003.

[162] J. van Hoorn, G. Dekker, and B. Jeffries, "Gestational diabetes versus obesity as risk factors for pregnancy-induced hypertensive disorders and fetal macrosomia," Australian and New Zealand Journal of Obstetrics and Gynaecology, vol. 42, no. 1, pp. 35-40, 2002.

[163] N. Jansson, A. Nilsfelt, M. Gellerstedt et al., "Maternal hormones linking maternal body mass index and dietary intake to birth weight," The American Journal of Clinical Nutrition, vol. 87, no. 6, pp. 1743-1749, 2008.

[164] S. M. Garn and S. D. Pesick, "Relationship between various maternal body mass measures and size of the newborn," The American Journal of Clinical Nutrition, vol. 36, no. 4, pp. 664$668,1982$.

[165] K. H. Morin, "Perinatal outcomes of obese women: a review of the literature," Journal of Obsetetric, Gynecologic and Neonatal Nursing, vol. 27, no. 4, pp. 431-440, 1998.

[166] G. C. Lu, D. J. Rouse, M. DuBard, S. Cliver, D. Kimberlin, and J. C. Hauth, "The effect of the increasing prevalence of maternal obesity on perinatal morbidity," American Journal of Obstetrics and Gynecology, vol. 185, no. 4, pp. 845-849, 2001.

[167] J. C. Rhodes, K. C. Schoendorf, and J. D. Parker, "Contribution of excess weight gain during pregnancy and macrosomia to the cesarean delivery rate, 1990-2000," Pediatrics, vol. 111, no. 5, pp. 1181-1185, 2003.

[168] U. M. Schaefer-Graf, M. Braurer, S. L. Kjos et al., "Determinants of fetal growth at different periods of pregnancies complicated by gestational diabetes mellitus of impaired glucose tolerance," Diabetes Care, vol. 26, no. 1, pp. 193-198, 2003. 
[169] A. K. Jenum, L. Sletner, N. Voldner et al., "The STORK Groruddalen research programme: a population-based cohort pregnancy in a multiethnic population. Rationale, methods, study population, and participation rates," Scandinavian Journal of Public Health, vol. 38, supplement 5, pp. 60-70, 2010.

[170] S. Bhattacharya, "Higher BMI in pregnant women association with a greater likelihood of pre-eclampsia, caesarian delivery, and higher offspring birth weight and body fat," BJOG, vol. 117, pp. 575-584, 2010.

[171] N. Farah, N. Maher, S. Barry, M. Kennelly, B. Stuart, and M. J. Turner, "Maternal morbid obesity and obstetric outcomes," Obesity Facts, vol. 2, no. 6, pp. 352-354, 2009.

[172] Y. Hiramatsu, H. Masuyama, Y. Mizutani, T. Kudo, N. Oguni, and Y. Oguni, "Heavy-for-date infants: their backgrounds and relationship with gestational diabetes," Journal of Obstetrics and Gynaecology Research, vol. 26, no. 3, pp. 193-198, 2000.

[173] L. D. O'Dell and W. F. Mengert, "The overweigh obstetric patient," Journal of the American Medical Association, vol. 128, no. 2, pp. 87-90, 1945.

[174] L. B. Nucci, M. I. Schmidt, B. B. Duncan, S. C. Fuchs, E. T. Fleck, and M. M. Santos Britto, "Nutritional status of pregnant women: prevalence and associated pregnancy outcomes," Revista de Saude Publica, vol. 35, no. 6, pp. 502-507, 2001.

[175] S. Bo, G. Menato, A. Signorile et al., "Obesity or diabetes: what is worse for the mother and for the baby?" Diabetes and Metabolism, vol. 29, no. 2 I, pp. 175-178, 2003.

[176] I. Inegöl Gümüş, F. Karakurt, A. Kargili, N. Öztürk Turhan, and M. Erkmen Uyar, "Association between prepregnancy body mass index, gestational weight gain, and perinatal outcomes," Turkish Journal of Medical Sciences, vol. 40, no. 3, pp. 365-370, 2010.

[177] A. Majumdar, S. Saleh, and C. K. Candelier, "Failure to recognise the impact of "moderate" obesity (BMI 3040) on adverse obstetric outcomes," Journal of Obstetrics \& Gynaecology, vol. 30, no. 6, pp. 567-570, 2010.

[178] R. T. Fortner, P. Pekow, C. G. Solomon, G. Markenson, and L. Chasan-Taber, "Prepregnancy body mass index, gestational weight gain, and risk of hypertensive pregnancy among Latina women," American Journal of Obstetrics and Gynecology, vol. 200, no. 2, pp. 167.e1-167.e7, 2008.

[179] O. Mamula, N. S. Severinski, M. Mamula, and S. Severinski, "Complications during pregnancy, labor and puerperium in women with increased BMI at pregnancy term," Central European Journal of Medicine, vol. 4, no. 1, pp. 71-75, 2009.

[180] N. E. Stotland, "Obesity and pregnancy," British Medical Journal, vol. 338, no. 7686, pp. 107-110, 2009.

[181] D. Rajasingam, P. T. Seed, A. L. Briley, A. H. Shennan, and L. Poston, "A prospective study of pregnancy outcome and biomarkers of oxidative stress in nulliparous obese women," American Journal of Obstetrics \& Gynecology, vol. 200, no. 4, pp. 395.e1-395.e9, 2009.

[182] Z. Chen, J. Du, L. Shao et al., "Prepregnancy body mass index, gestational weight gain, and pregnancy outcomes in China," International Journal of Gynecology and Obstetrics, vol. 109, no. 1, pp. 41-44, 2010.

[183] J. R. Green, L. B. Schumacher, I. G. Pawson, J. C. Partridge, and N. Kretchmer, "Influence of maternal body habitus and glucose tolerance on birth weight," Obstetrics and Gynecology, vol. 78, no. 2, pp. 235-240, 1991.

[184] P. H. D. C. Rondó and A. M. Tomkins, "Maternal and neonatal anthropometry," Annals of Tropical Paediatrics, vol. 19, no. 4, pp. 349-356, 1999.
[185] J. K. Lake, C. Power, and T. J. Cole, "Women's reproductive health: the role of body mass index in early and adult life," International Journal of Obesity, vol. 21, no. 6, pp. 432-438, 1997.

[186] P. R. Olmos, A. P. Araya-Del-Pino, C. A. González-Carvello et al., "Near-optimal glycemic control in Chilean women with pregestational type-2 diabetes: persistent macrosomia relates to maternal pre-pregnancy overweight," Diabetes Research and Clinical Practice, vol. 85, no. 1, pp. 53-60, 2009.

[187] Y. Friedlander, O. Manor, O. Paltiel et al., "Birth weight of offspring, maternal pre-pregnancy characteristics, and mortality of mothers: the Jerusalem perinatal study cohort," Annals of Epidemiology, vol. 19, no. 2, pp. 112-117, 2009.

[188] Y. Yogev and P. M. Catalano, "Pregnancy and obesity," Obstetrics \& Gynecology Clinics of North America, vol. 36, no. 2, pp. 285300, 2009.

[189] S. Haeri, I. Guichard, A. M. Baker, S. Saddlemire, and K. A. Boggess, "The effect of teenage maternal obesity on perinatal outcomes," Obstetrics and Gynecology, vol. 113, no. 2, pp. 300304, 2009.

[190] T. T. Lao and L. F. Ho, "Impaired glucose tolerance and pregnancy outcome in Chinese women with high body mass index," Human Reproduction, vol. 15, no. 8, pp. 1826-1829, 2000.

[191] J. D. Steinfeld, S. Valentine, T. Lerer, C. J. Ingardia, J. R. Wax, and S. L. Curry, "Obesity-related complications of pregnancy vary by race," The Journal of Maternal-Fetal Medicine, vol. 9, pp. 238-241, 2000.

[192] S. A. Lederman, G. Alfasi, and R. J. Deckelbaum, "Pregnancyassociated obesity in black women in New York City," Maternal and Child Health Journal, vol. 6, no. 1, pp. 37-42, 2002.

[193] E. Oken and M. W. Gillman, "Fetal origins of obesity," Obesity Research, vol. 11, no. 4, pp. 496-506, 2003.

[194] J. E. Ramsay and I. A. Greer, "Obesity in pregnancy," Fetal and Maternal Medicine Review, vol. 15, no. 2, pp. 109-132, 2004.

[195] K. C. Quack Loetscher, S. Selvin, R. Zimmerman, and B. Abrams, "Ethnic-cultural background, maternal body size and pregnancy outcomes in a Diverse Swiss Cohort," Women and Health, vol. 45, no. 2, pp. 25-40, 2007.

[196] A. Chen, M. A. Klebanoff, and O. Basso, "Pre-pregnancy body mass index change between pregnancies and preterm birth in the following pregnancy," Paediatric and Perinatal Epidemiology, vol. 23, no. 3, pp. 207-215, 2009.

[197] R. Wuntakal and T. Hollingworth, "The implications of obesity on pregnancy," Obstetrics, Gynaecology and Reproductive Medicine, vol. 19, no. 12, pp. 344-349, 2009.

[198] R. L. Goldenberg, "Prepregnancy weight and pregnancy outcome," Journal of the American Medical Association, vol. 275, no. 14, pp. 1127-1128, 1996.

[199] H. M. Wolfe and T. L. Gross, "Obesity in pregnancy," Clinical Obstetrics and Gynecology, vol. 37, no. 3, pp. 596-604, 1994.

[200] H. E. Mighty and J. O. Fahey, "Obesity and pregnancy complications," Current Diabetes Reports, vol. 7, no. 4, pp. 289-294, 2007.

[201] E. Mobasheri and M. J. Golalipour, "The effect of pre-pregnancy body mass index on gestational weight gain and pregnancy outcome in Gorgan, North Iran," Journal of Medical Sciences, vol. 7, no. 5, pp. 905-908, 2007.

[202] L. H. Kunz and J. C. King, "Impact of maternal nutrition and metabolism on health of the offspring," Seminars in Fetal and Neonatal Medicine, vol. 12, no. 1, pp. 71-77, 2007.

[203] L. C. Seligman, B. B. Duncan, L. Branchtein, D. S. Miranda Gaio, S. S. Mengue, and M. I. Schmidt, "Obesity and gestational weight gain: cesarean delivery and labor complications," Revista de Saude Publica, vol. 40, no. 3, pp. 457-465, 2006. 
[204] J. Brockelsby and M. Dresner, "Obesity and pregnancy," Current Anaesthesia and Critical Care, vol. 17, no. 3-4, pp. 125-129, 2006.

[205] L. Irvine and R. Shaw, "The impact of obesity on obstetric outcomes," Current Obstetrics and Gynaecology, vol. 16, no. 4, pp. 242-246, 2006.

[206] P. G. Crosignani, "Nutrition and reproduction in women," Human Reproduction Update, vol. 12, no. 3, pp. 193-207, 2006.

[207] S. Cnattingius and M. Lambe, "Trends in smoking and overweight during pregnancy: prevalence, risks of pregnancy complications, and adverse pregnancy outcomes," Seminars in Perinatology, vol. 26, no. 4, pp. 286-295, 2002.

[208] L. C. Castro and R. L. Avina, "Maternal obesity and pregnancy outcomes," Current Opinion in Obstetrics and Gynecology, vol. 14, no. 6, pp. 601-606, 2002.

[209] N. Okun, A. Verma, B. F. Mitchell, and G. Flowerdew, "Relative importance of maternal constitutional factors and glucose intolerance of pregnancy in the development of newborn macrosomia," The Journal of Maternal-Fetal Medicine, vol. 6, no. 5, pp. 285-290, 1997.

[210] P. Rantakallio, E. Läärä, M. Koiranen, and A. Sarpola, "Maternal build and pregnancy outcome," Journal of Clinical Epidemiology, vol. 48, no. 2, pp. 199-207, 1995.

[211] D. Ogunyemi, S. Hullett, J. Leeper, and A. Risk, "Prepregnancy body mass index, weight gain during pregnancy, and perinatal outcome in a rural black population," The Journal of MaternalFetal Medicine, vol. 7, pp. 190-193, 1998.

[212] R. L. Naeye, "Maternal body weight and pregnancy outcome," The American Journal of Clinical Nutrition, vol. 52, no. 2, pp. 273-279, 1990.

[213] W. L. Hellerstedt, J. H. Hirnes, M. Story, I. R. Alton, and L. E. Edwards, "The effects of cigarette smoking and gestational weight change on birth outcomes in obese and normal-weight women," American Journal of Public Health, vol. 87, no. 4, pp. 591-596, 1997.

[214] F. Galtier-Dereure, C. Boegner, and J. Bringer, "Obesity and pregnancy: complications and cost," The American Journal of Clinical Nutrition, vol. 71, no. 5, pp. 1242S-1248S, 2000.

[215] S. Rossner and A. Ohlin, "Maternal body weight and relation to birth weight," Acta Obstetricia et Gynecologica Scandinavica, vol. 69, no. 6, pp. 475-478, 1990.

[216] U. Ekblad and S. Grenman, "Maternal weight, weight gain during pregnancy and pregnancy outcome," International Journal of Gynecology and Obstetrics, vol. 39, no. 4, pp. 277-283, 1992.

[217] C. Aydin, A. Baloglu, A. Yavuzcan, and A. Inci, “The effect of body mass index value during labor on pregnancy outcomes in Turkish population (obesity and pregnancy outcomes)," Archives of Gynecology and Obstetrics, vol. 281, no. 1, pp. 49-54, 2010.

[218] K. K. Ong, B. Diderholm, G. Salzano et al., "Pregnancy insulin, glucose, and BMI contribute to birth outcomes in nondiabetic mothers," Diabetes Care, vol. 31, no. 11, pp. 2193-2197, 2008.

[219] R. Ruager-Martin, M. J. Hyde, and N. Modi, "Maternal obesity and infant outcomes," Early Human Development, vol. 86, no. 11, pp. 715-722, 2010.

[220] A. Dixit and J. C. Girling, "Obesity and pregnancy," Journal of Obstetrics \& Gynaecology, vol. 28, no. 1, pp. 14-23, 2008.

[221] A. Chen, S. A. Feresu, C. Fernandez, and W. J. Rogan, "Maternal obesity and the risk of infant death in the United States," Epidemiology, vol. 20, no. 1, pp. 74-81, 2009.

[222] C. Jevitt, "Pregnancy complicated by obesity: midwifery management," Journal of Midwifery and Women's Health, vol. 54, no. 6, pp. 445-451, 2009.
[223] K. Wataba, T. Mizutani, K. Wasada, M. Morine, T. Sugiyama, and N. Suehara, "Impact of prepregnant body mass index and maternal weight gain on the risk of pregnancy complications in Japanese women," Acta Obstetricia et Gynecologica Scandinavica, vol. 85, no. 3, pp. 269-276, 2006.

[224] E. Sheiner, A. Levy, T. S. Menes, D. Silverberg, M. Katz, and M. Mazor, "Maternal obesity as an independent risk factor for caesarean delivery," Paediatric and Perinatal Epidemiology, vol. 18, no. 3, pp. 196-201, 2004.

[225] P. M. Catalano and H. M. Ehrenberg, "The short- and longterm implications of maternal obesity on the mother and her offspring," BJOG, vol. 113, no. 10, pp. 1126-1133, 2006.

[226] C. K. H. Yu, T. G. Teoh, and S. Robinson, "Obesity in pregnancy," An International Journal of Obstetrics and Gynaecology, vol. 113, no. 10, pp. 1117-1125, 2006.

[227] S. Kirchengast and B. Hartmann, "Impact of maternal age and maternal somatic characteristics on newborn size," American Journal of Human Biology, vol. 15, no. 2, pp. 220-228, 2003.

[228] W. Kabiru and B. D. Raynor, "Obstetric outcomes associated with increase in BMI category during pregnancy," American Journal of Obstetrics \& Gynecology, vol. 191, no. 3, pp. 928-932, 2004.

[229] T. Gross, R. J. Sokol, and K. C. King, "Obesity in pregnancy: risks and outcome," Obstetrics and Gynecology, vol. 56, no. 4, pp. 446-450, 1980.

[230] K. R. Andreasen, M. L. Andersen, and A. L. Schantz, "Obesity and pregnancy," Acta Obstetricia et Gynecologica Scandinavica, vol. 83, no. 11, pp. 1022-1029, 2004.

[231] W. N. Spellacy, S. Miller, A. Winegar, and P. Q. Peterson, "Macrosomia-maternal characteristics and infant complications," Obstetrics and Gynecology, vol. 66, no. 2, pp. 158-161, 1985.

[232] F. R. Witter, L. E. Caulfield, and R. J. Stoltzfus, "Influence of maternal anthropometric status and birth weight on the risk of cesarean delivery," Obstetrics and Gynecology, vol. 85, no. 6, pp. 947-951, 1995.

[233] Z. Yekta, H. Ayatollahi, R. Porali, and A. Farzin, "The effect of pre-pregnancy body mass index and gestational weight gain on pregnancy outcomes in urban care settings in Urmia-Iran," BMC Pregnancy and Childbirth, vol. 6, article 15, 2006.

[234] N. Phithakwatchara and V. Titapant, "The effect of prepregnancy weight on delivery outcome and birth weight in potential diabetic patients with normal screening for gestational diabetes mellitus in Siriraj Hospital," Journal of the Medical Association of Thailand, vol. 90, no. 2, pp. 229-236, 2007.

[235] J. G. Ray, M. J. Vermeulen, J. L. Shapiro, and A. B. Kenshole, "Maternal and neonatal outcomes in pregestational and gestational diabetes mellitus, and the influence of maternal obesity and weight gain: the DEPOSIT study," QJM, vol. 94, no. 7, pp. 347-356, 2001.

[236] N. E. Stotland, A. B. Caughey, E. M. Breed, and G. J. Escobar, "Risk factors and obstetric complications associated with macrosomia," International Journal of Gynecology \& Obstetrics, vol. 87, no. 3, pp. 220-226, 2004.

[237] L. C. P. G. M. de Groot, "High maternal body weight and pregnancy outcome," Nutrition Reviews, vol. 57, no. 2, pp. 6264, 1999.

[238] C. M. Boney, A. Verma, R. Tucker, and B. R. Vohr, "Metabolic syndrome in childhood: association with birth weight, maternal obesity, and gestational diabetes mellitus," Pediatrics, vol. 115, no. 3, pp. e290-e296, 2005. 
[239] C. Calandra, D. A. Abell, and N. A. Beischer, "Maternal obesity in pregnancy," Obstetrics and Gynecology, vol. 57, no. 1, pp. 8-12, 1981.

[240] D. H. Hood and D. M. Dewan, "Anesthetic and obstetric outcome in morbidly obese parturients," Anesthesiology, vol. 79, no. 6, pp. 1210-1218, 1993.

[241] D. Bowers and W. R. Cohen, "Obesity and related pregnancy complications in an inner-city clinic," Journal of Perinatology, vol. 19, no. 3, pp. 216-219, 1999.

[242] E. Ricci, F. Parazzini, F. Chiaffarino, S. Cipriani, and G. Polverino, "Pre-pregnancy body mass index, maternal weight gain during pregnancy and risk of small-for-gestational age birth: results from a casecontrol study in Italy," The Journal of Maternal-Fetal and Neonatal Medicine, vol. 23, no. 6, pp. 501505, 2010.

[243] F. P. Dunne, G. Avalos, M. Durkan et al., "ATLANTIC DIP: pregnancy outcome for women with pregestational diabetes along the Irish Atlantic seaboard," Diabetes Care, vol. 32, no. 7, pp. 1205-1206, 2009.

[244] L. A. Owens, E. P. O’Sullivan, B. Kirwan, G. Avalos, G. Gaffney, and F. Dunne, "ATLANTIC DIP: the impact of obesity on pregnancy outcome in glucose-tolerant women," Diabetes Care, vol. 33, no. 3, pp. 577-579, 2010.

[245] E. Fuller-Thomson, M. Rotermann, and J. G. Ray, "Elevated risk factors for adverse pregnancy outcomes among FilipinaCanadian women," Journal of Obstetrics and Gynaecology Canada, vol. 32, no. 2, pp. 113-119, 2010.

[246] E. A. Nohr, N. J. Timpson, C. S. Andersen, G. D. Smith, J. Olsen, and T. I. A. Sørensen, "Severe obesity in young women and reproductive health: the danish national birth cohort," PLoS ONE, vol. 4, no. 12, Article ID e8444, 2009.

[247] M. Chen, C. McNiff, J. Madan, E. Goodman, J. M. Davis, and O. Dammann, "Maternal obesity and neonatal Apgar scores," The Journal of Maternal-Fetal and Neonatal Medicine, vol. 23, no. 1, pp. 89-95, 2010.

[248] J. R. Wax, "Risks and management of obesity in pregnancy: current controversies," Current Opinion in Obstetrics and Gynecology, vol. 21, no. 2, pp. 117-123, 2009.

[249] F. C. Denison, G. Norrie, B. Graham, J. Lynch, N. Harper, and R. M. Reynolds, "Increased maternal BMI is associated with an increased risk of minor complications during pregnancy with consequent cost implications," BJOG: An International Journal of Obstetrics \& Gynaecology, vol. 116, no. 11, pp. 1467-1472, 2009.

[250] S. L. Boulet, G. R. Alexander, and H. M. Salihu, "Secular trends in cesarean delivery rates among macrosomic deliveries in the United States, 1989 to 2002," Journal of Perinatology, vol. 25, no. 9, pp. 569-576, 2005.

[251] M. S. Kramer, I. Morin, H. Yang et al., "Why are babies getting bigger? Temporal trends in fetal growth and its determinants," Journal of Pediatrics, vol. 141, no. 4, pp. 538-542, 2002.

[252] L. F. Hall and A. G. Neubert, "Obesity and pregnancy," Obstetrical \& Gynecological Survey, vol. 60, no. 4, pp. 253-260, 2005.

[253] J. K. Basu, C. M. Jeketera, and D. Basu, "Obesity and its outcomes among pregnant South African women," International Journal of Gynecology and Obstetrics, vol. 110, no. 2, pp. 101-104, 2010.

[254] C. R. Gale, M. K. Javaid, S. M. Robinson, C. M. Law, K. M. Godfrey, and C. Cooper, "Maternal size in pregnancy and body composition in children," The Journal of Clinical Endocrinology and Metabolism, vol. 92, no. 10, pp. 3904-3911, 2007.
[255] M. C. Alanis, W. H. Goodnight, E. G. Hill, C. J. Robinson, M. S. Villers, and D. D. Johnson, "Maternal super-obesity (body mass index $\geq 50$ ) and adverse pregnancy outcomes," Acta Obstetricia et Gynecologica Scandinavica, vol. 89, no. 7, pp. 924-930, 2010.

[256] I. Hendler, R. L. Goldenberg, B. M. Mercer et al., "The Preterm Prediction study: association between maternal body mass index and spontaneous and indicated preterm birth," American Journal of Obstetrics \& Gynecology, vol. 192, no. 3, pp. 882-886, 2005.

[257] A. Mancuso, R. D’Anna, and R. Leonardi, "Pregnancy in the obese patient," European Journal of Obstetrics Gynecology and Reproductive Biology, vol. 39, no. 2, pp. 83-86, 1991.

[258] F. Mardones-Santander, G. Salazar, P. Rosso, and L. Villarroel, "Maternal body composition near term and birth weight," Obstetrics \& Gynecology, vol. 91, no. 6, pp. 873-877, 1998.

[259] D. Ogunyemi, S. Hullett, J. Leeper, and A. Risk, "Prepregnancy body mass index, weight gain during pregnancy and perinatal outcome in a rural black population," The Journal of MaternalFetal Medicine, vol. 7, pp. 190-193, 1998.

[260] W. Ricart, J. López, J. Mozas et al., "Maternal glucose tolerance status influences the risk of macrosomia in male but not in female fetuses," Journal of Epidemiology and Community Health, vol. 63, no. 1, pp. 64-68, 2009.

[261] T. J. Rosenberg, S. Garbers, W. Chavkin, and M. A. Chiasson, "Prepregnancy weight and adverse perinatal outcomes in an ethnically diverse population," Obstetrics \& Gynecology, vol. 102, no. 5, pp. 1022-1027, 2003.

[262] M. F. Sewell, L. Huston-Presley, D. M. Super, and P. Catalano, "Increased neonatal fat mass, not lean body mass, is associated with maternal obesity," American Journal of Obstetrics and Gynecology, vol. 195, no. 4, pp. 1100-1103, 2006.

[263] A. Vahratian, A. M. Siega-Riz, D. A. Savitz, and J. Zhang, "Maternal pre-pregnancy overweight and obesity and the risk of cesarean delivery in nulliparous women," Annals of Epidemiology, vol. 15, no. 7, pp. 467-474, 2005.

[264] T. R. Varma, "Maternal weight and weight gain in pregnancy and obstetric outcome," International Journal of Gynecology and Obstetrics, vol. 22, no. 2, pp. 161-166, 1984.

[265] I. Wikstrom, O. Axelsson, and R. Bergstrom, "Maternal factors associated with high birth weight," Acta Obstetricia et Gynecologica Scandinavica, vol. 70, no. 1, pp. 55-61, 1991.

[266] S. Blissing, R. Roloff, G. Girschick, T. Frambach, and J. Dietl, "Neonatal results of prgenancies in overweight and obese mothers at the University of Würzburg Gynaecology Clinica comparison of the years 1980 and 2005," Zeitschrift fur Geburtshilfe und Neonatologie, vol. 212, no. 3, pp. 94-99, 2008.

[267] K. Hänseroth, W. Distler, C. Kamin, and K. Nitzsche, "Pregnancy course, delivery and post-partum period in adipose women," Geburtshilfe und Frauenheilkunde, vol. 67, no. 1, pp. 3337, 2007 (German).

[268] P. Berle, B. Misselwitz, and J. Scharlau, "Maternal risks for newborn macrosomia, incidence of a shoulder dystocia and of damages of the plexus brachialis," Zeitschrift für Geburtshilfe und Neonatologie, vol. 207, no. 4, pp. 148-152, 2003.

[269] B.-T. Marlena, K.-K. Urszula, K.-B. Agata et al., "The course of pregnancy and perinatal period in overweight or obese pregnant women with regard to the condition of the newbornown experience," Ginekologia Polska, vol. 80, no. 11, pp. 845-850, 2009.

[270] I. Strzelec-Polewka, A. Drosdzol, and V. Skrzypulec, "Obesity and its complications for pregnant women," Wiedomosci Lekarskie, vol. 62, no. 4, pp. 257-261, 2009 (Polish). 
[271] D. Szostak-Wegierek, K. Szamotulska, and L. Szponar, "Influence of maternal nutrition on infant birthweight," Ginekologia Polska, vol. 75, no. 9, pp. 692-698, 2004.

[272] T. D. Valentin, J. A. Sørensen, and E. E. Andreasen, "Obese pregnant women have complicated deliveries," Ugeskrift for Loger, vol. 165, no. 10, pp. 1027-1030, 2003.

[273] E. Atalah S and R. Castro S, "Maternal obesity and reproductive risk," Revista Medica de Chile, vol. 132, no. 8, pp. 923-930, 2004.

[274] G. R. Gutierrez, F. J. U. Ortiz, A. L. P. P. de Leon, and N. Amador, "Morbilidada materno-fetal en embarazadas obesas," Ginecología y Obstetricia de México, vol. 74, pp. 483-487, 2006 (Spanish).

[275] C. Hamon, S. Fanello, L. Catala, and E. Parot, "Maternal obesity: effects on labor and delivery. "Excluding other diseases that might modify obstetrical management"', Journal de Gynécologie Obstétrique et Biologie de la Reproduction, vol. 34, no. 2, pp. 109114, 2005 (French).

[276] E. Grossetti, G. Beucher, A. Régeasse, N. Lamendour, M. Herlicoviez, and M. Dreyfus, "Morbid obesity and perinatal complications," Journal de Gynecologie Obstetrique et Biologie de la Reproduction, vol. 33, no. 8, pp. 739-744, 2004 (French).

[277] F. Djrolo, A. M. Obey, J. De Souza, I. Takpara, P. Santos, and E. Alihonou, "Influence of maternal weight on pregnancy outcome in Cotonou (Benin)," Journal de Gynecologie Obstetrique et Biologie de la Reproduction, vol. 31, no. 3, pp. 243-247, 2002.

[278] J. Šegregur, "The effect of body weight, body mass index and gestational weight gain of pregnant women on pregnancy outcome," Gynaecologia et Perinatologia, vol. 17, no. 1, pp. 9-14, 2008 (Croatian).

[279] S. Abu Yaacob, F. A. Saad, H. A. Sharara, L. Khalifa, A. A. Manther, and Y. A. Rashed, "The effect of obesity in pregnancy on perinatal outcome in Qatar," Qatar Medical Journal, vol. 11, no. 2, pp. 32-35, 2002.

[280] A. Langford, C. Joshu, J. J. Chang, T. Myles, and T. Leet, "Does gestational weight gain affect the risk of adverse maternal and infant outcomes in overweight women?" Maternal and Child Health Journal, vol. 15, no. 7, pp. 860-865, 2011.

[281] G. di Cianni, L. Benzi, P. Bottone et al., "Neonatal outcome and obstetric complications in women with gestational diabetes: effects of maternal body mass index," International Journal of Obesity, vol. 20, no. 5, pp. 445-449, 1996.

[282] W. Zhou and J. Olsen, "Gestational weight gain as a predictor of birth and placenta weight according to pre-pregnancy body mass index," Acta Obstetricia et Gynecologica Scandinavica, vol. 76, no. 4, pp. 300-307, 1997.

[283] N. J. Jain, C. E. Denk, L. K. Kruse, and V. Dandolu, "Maternal obesity: can pregnancy weight gain modify risk of selected adverse pregnancy outcomes?", American Journal of Perinatology, vol. 24, no. 5, pp. 291-298, 2007.

[284] S. Potti, C. S. Sliwinski, N. J. Jain, and V. Dandolu, "Obstetric outcomes in normal weight and obese women in relation to gestational weight gain: comparison between institute of medicine guidelines and cedergren criteria," American Journal of Perinatology, vol. 27, no. 5, pp. 415-420, 2010.

[285] S. Joy, N. Istwan, D. Rhea, C. Desch, and G. Stanziano, "The impact of maternal obesity on the incidence of adverse pregnancy outcomes in high-risk term pregnancies," American Journal of Perinatology, vol. 26, no. 5, pp. 345-349, 2009.

[286] A. A. Flick, K. F. Brookfield, L. de la Torre, C. M. Tudela, L. Duthely, and V. H. González-Quintero, "Excessive weight gain among obese women and pregnancy outcomes," American Journal of Perinatology, vol. 27, no. 4, pp. 333-338, 2010.
[287] L. E. Edwards, W. F. Dickes, I. R. Alton, and E. Y. Hakanson, "Pregnancy in the massively obese: course, outcome, and obesity prognosis of the infant," American Journal of Obstetrics and Gynecology, vol. 131, no. 5, pp. 479-483, 1978.

[288] J. A. Garbaciak Jr., M. Richter, S. Miller, and J. J. Barton, "Maternal weight and pregnancy complications," American Journal of Obstetrics and Gynecology, vol. 152, no. 2, pp. 238245, 1985.

[289] D. K. Waller and T. E. Dawson, "Relationship between maternal obesity and adverse pregnancy outcomes," Nestle Nutrition Workshop Series: Pediatric Program, vol. 55, pp. 197-211, 2005.

[290] S. Begum, S. N. Huda, N. Musarrat, S. Ahmed, L. A. Banu, and S. M. K. Ali, "Nutritional status and birth outcomes of the diabetic and non-diabetic pregnant women," Bangladesh Medical Research Council Bulletin, vol. 28, no. 3, pp. 97-103, 2002.

[291] B. Abrams and J. Parker, "Overweight and pregnancy complications," International Journal of Obesity, vol. 12, no. 4, pp. 293303, 1988.

[292] J. H. Perlow, M. A. Morgan, D. Montgomery, C. V. Towers, and M. Porto, "Perinatal outcome in pregnancy complicated by massive obesity," American Journal of Obstetrics and Gynecology, vol. 167, no. 4 I, pp. 958-962, 1992.

[293] U. Magriples, T. S. Kershaw, S. S. Rising, C. Westdahl, and J. R. Ickovics, "The effects of obesity and weight gain in young women on obstetric outcomes," American Journal of Perinatology, vol. 26, no. 5, pp. 365-371, 2009.

[294] J. W. C. Johnson, J. A. Longmate, and B. Frentzen, "Excessive maternal weight and pregnancy outcome," The American Journal of Obstetrics and Gynecology, vol. 167, no. 2, pp. 353-372, 1992.

[295] F. Galtier-Dereure, F. Montpeyroux, P. Boulot, J. Bringer, and C. Jaffiol, "Weight excess before pregnancy: complications and cost," American Journal of Clinical Nutrition, vol. 71, no. 5, pp. 1242S-1248S, 2000.

[296] B. F. Abrams and R. K. Laros Jr., "Prepregnancy weight, weight gain, and birth weight," American Journal of Obstetrics \& Gynecology, vol. 154, no. 3, pp. 503-509, 1986.

[297] E. Burstein, A. Levy, M. Mazor, A. Wiznitzer, and E. Sheiner, "Pregnancy outcome among obese women: a prospective study," The American Journal of Perinatology, vol. 25, no. 9, pp. 561-566, 2008.

[298] Z. Russell, H. M. Salihu, O. Lynch, A. P. Alio, and V. Belogolovkin, "The association of prepregnancy body mass index with pregnancy outcomes in triplet gestations," American Journal of Perinatology, vol. 27, no. 1, pp. 41-46, 2010.

[299] M. C. Mitchell and E. Lerner, "A comparison of pregnancy outcome in overweight and normal weight women," Journal of the American College of Nutrition, vol. 8, no. 6, pp. 617-624, 1989.

[300] S. R. Johnson, B. H. Kolberg, M. W. Varner, and L. D. Railsback, "Maternal obesity and pregnancy," Surgery Gynecology and Obstetrics, vol. 164, no. 5, pp. 431-437, 1987.

[301] J. E. Fiala, J. F. X. Egan, and M. Lashgari, "The influence of body mass index on pregnancy outcomes," Connecticut Medicine, vol. 70, no. 1, pp. 21-23, 2006.

[302] N. Heiskanen, K. Raatikainen, and S. Heinonen, "Fetal macrosomia-a continuing obstetric challenge," Biology of the Neonate, vol. 90, no. 2, pp. 98-103, 2006.

[303] C. Savona-Ventura, S. Grima, and K. Vella, "Maternal BMI and antenatal weight gain as determinants of obstetric outcome," International Journal of Diabetes and Metabolism, vol. 16, no. 2, pp. 53-56, 2008. 
[304] C. Savona-Ventura and M. Gatt, "Short-term obstetric outcomes in obese Maltese women," International Journal of Diabetes and Metabolism, vol. 14, no. 2, pp. 88-91, 2006.

[305] P. Kalk, F. Guthmann, K. Krause et al., "Impact of maternal body mass index on neonatal outcome," European Journal of Medical Research, vol. 14, no. 5, pp. 216-222, 2009.

[306] H. M. Wolfe, I. E. Zador, T. L. Gross, S. S. Martier, and R. J. Sokol, "The clinical utility of maternal body mass index in pregnancy," American Journal of Obstetrics \& Gynecology, vol. 164, no. 5, pp. 1306-1310, 1991.

[307] E. A. Khorshid, T. A. Elbeheidy, and A. M. Quinaibi, "Risk of morbid obesity with pregnancy," Saudi Medical Journal, vol. 25, no. 1, pp. 121-122, 2004.

[308] The World Bank Group, The World Bank: Working for a World Free of Poverty, 2012, http://data.worldbank.org/.

[309] F. Ahlsson, B. Diderholm, B. Jonsson et al., "Insulin resistance, a link between maternal overweight and fetal macrosomia in nondiabetic pregnancies," Hormone Research in Paediatrics, vol. 74, no. 4, pp. 267-274, 2010.

[310] M. L. S. Lindegaard, P. Damm, E. R. Mathiesen, and L. B. Nielsen, "Placental triglyceride accumulation in maternal type 1 diabetes is associated with increased lipase gene expression," Journal of Lipid Research, vol. 47, no. 11, pp. 2581-2588, 2006.

[311] A. Russell, S. Gillespie, S. Satya, and L. M. Gaudet, "Assessing the accuracy of pregnant women in recalling pre-pregnancy weight and gestational weight gain," Journal of Obstetrics and Gynaecology Canada, vol. 35, no. 9, pp. 802-809, 2013. 


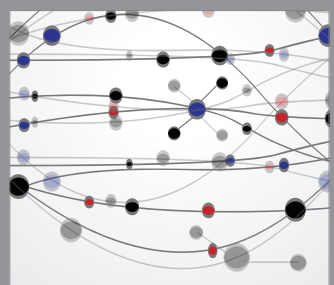

The Scientific World Journal
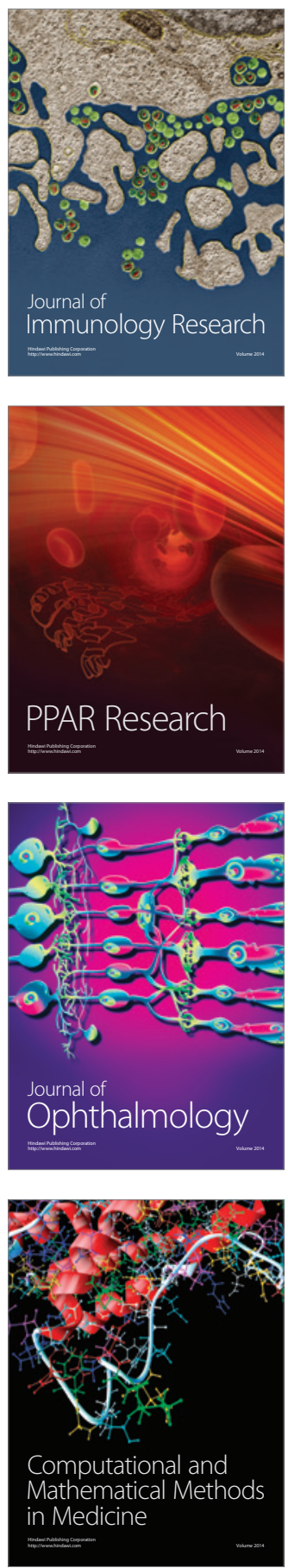

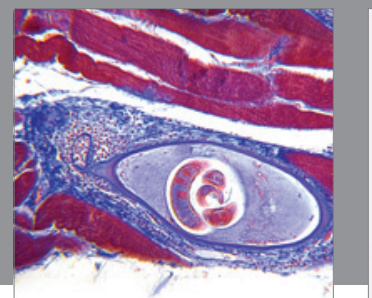

Gastroenterology

Research and Practice
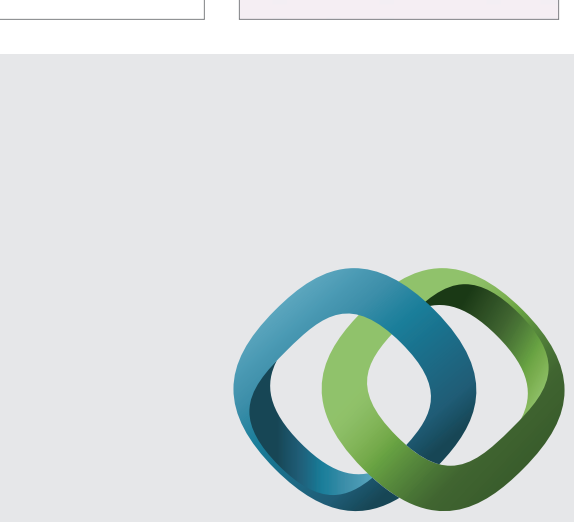

\section{Hindawi}

Submit your manuscripts at

http://www.hindawi.com
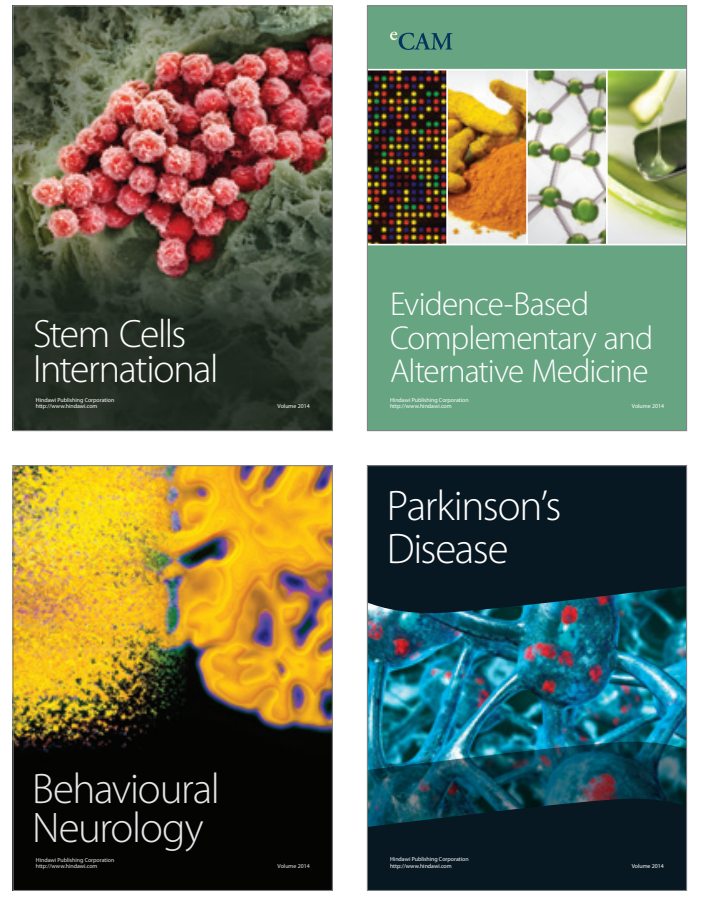
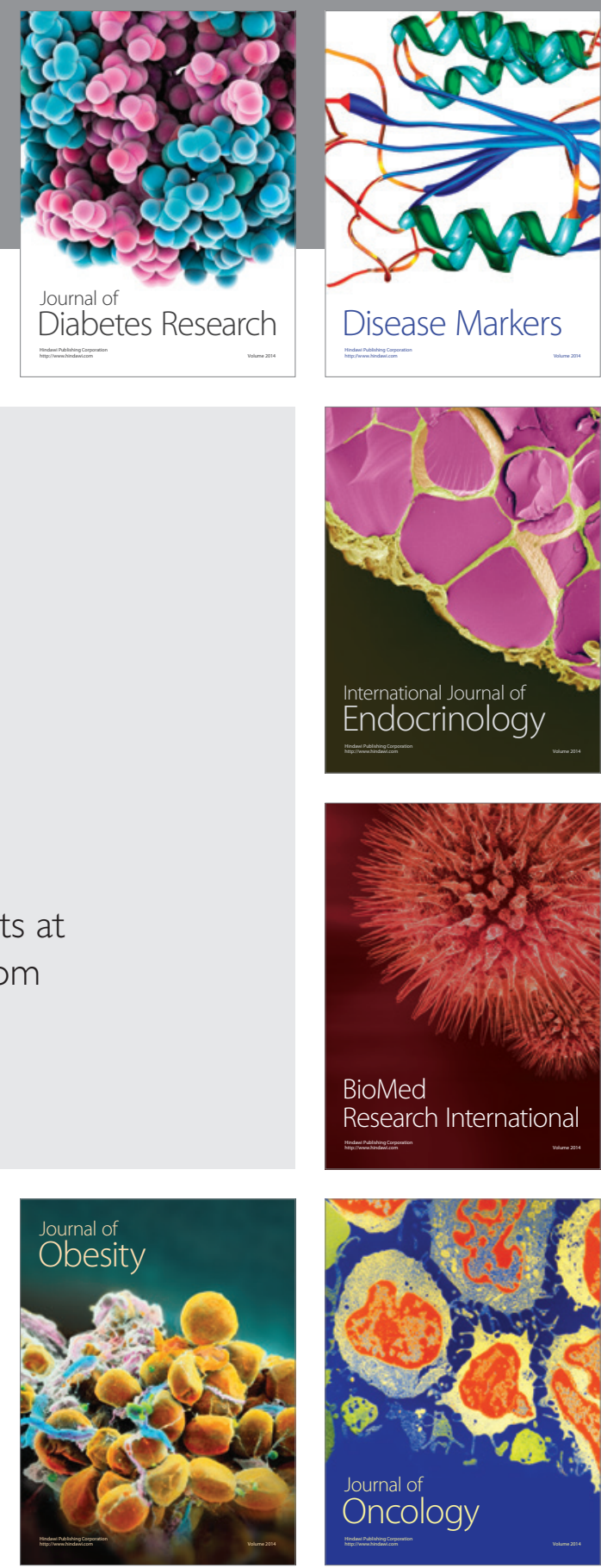

Disease Markers
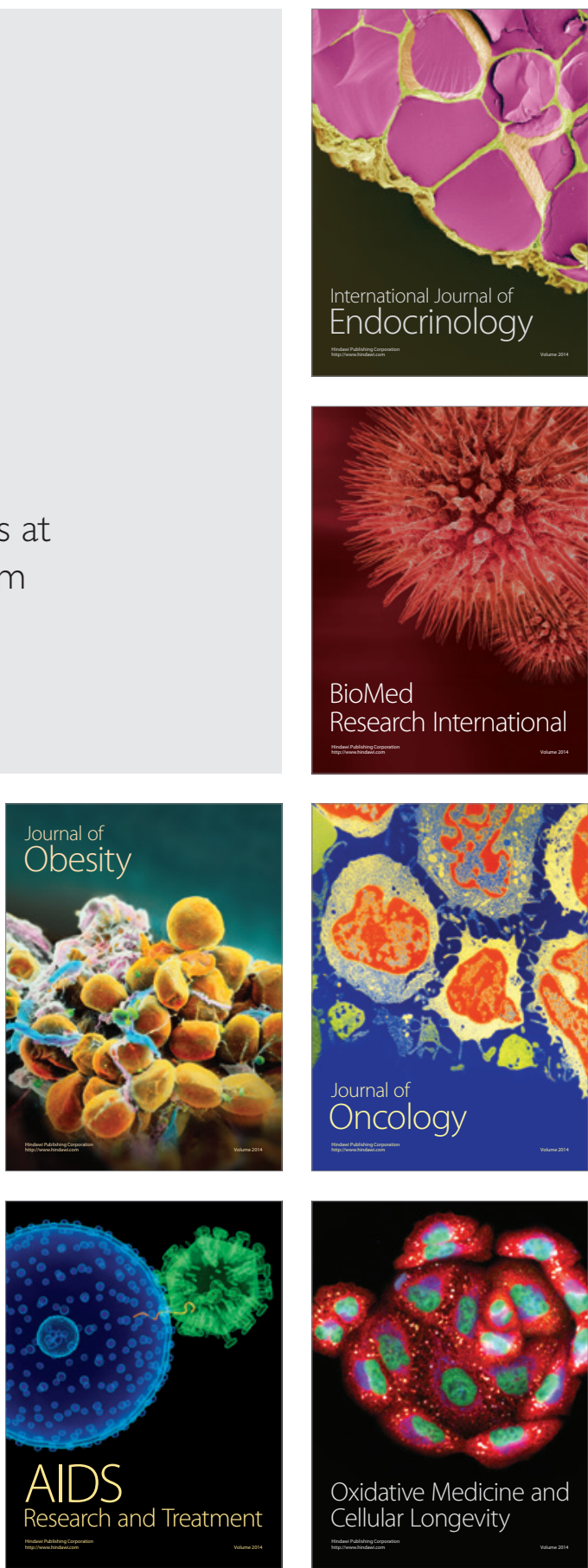